\title{
A STUDY ON SENSITIVITY OF SEISMIC SITE AMPLIFICATION FACTORS TO SITE CONDITIONS FOR BRIDGES
}

\author{
Muhammad Tariq A. Chaudhary ${ }^{1}$
}

(Submitted July 2017; Reviewed November 2017; Accepted July 2018)

\begin{abstract}
Seismic site amplification factors and seismic design spectra for bridges are influenced by site conditions that include geotechnical properties of soil strata as well as the geological setting. All modern seismic design codes recognize this fact and assign design spectral shapes based on site conditions or specify a 2-parameter model with site amplification factors as a function of site class, seismic intensity and vibration period (short and long). Design codes made a number of assumptions related to the site conditions while specifying the values of short $\left(\mathrm{F}_{\mathrm{a}}\right)$ and long period $\left(\mathrm{F}_{\mathrm{v}}\right)$ site amplification factors. Making these assumptions was necessary due to vast variation in site properties and limited availability of actual strong motion records on all site conditions and seismic setting in a region. This paper conducted a sensitivity analysis for site amplification factors for site classes C and D in the AASHTO bridge design code by performing a 1-D site response analysis in which values of site parameters like strata depth, travel-time averaged shear wave velocity in the top $30 \mathrm{~m}$ strata $\left(\mathrm{V}_{\mathrm{s} 30}\right)$, plasticity index $(\mathrm{PI})$, impedance contrast ratio (ICR) and intensity of seismic ground motion were varied. The results were analyzed to identify the site parameters that impacted $F_{a}$ and $F_{v}$ values for site classes $C$ and $D$. The computed $F_{a}$ and $F_{v}$ values were compared with the corresponding values in the AASHTO bridge design code and it was found that the code-based $F_{a}$ and $F_{v}$ values were generally underestimated and overestimated respectively.
\end{abstract}

\section{INTRODUCTION}

Influence of site conditions (geological setting and geotechnical properties) on seismic design spectra and site amplification factors is well recognized in modern seismic design codes [1] The AASHTO bridge design code in the United States [2] caters for the site effects by classifying the site conditions into six classes based on three methods for the top $30 \mathrm{~m}$ depth of the strata: (i) travel-time averaged shear wave velocity, $V_{\mathrm{s} 30}$ (ii) average standard penetration test (SPT) $\bar{N}$ values and (iii) average undrained shear strength, $\bar{s}_{u}$. It is to be noted that method (i) i.e. $V_{\mathrm{s} 30}$ is the preferred method for site classification in the US practice. Design spectrum for a bridge site is constructed based on its mapped peak ground acceleration (PGA), short period $(0.2 \mathrm{~s})$ spectral acceleration, $\mathrm{S}_{\mathrm{s}}$, and long period $(1.0 \mathrm{~s})$ spectral acceleration, $\mathrm{S}_{1}$, along with site amplification factors FPGA, $F_{a}$ and $F_{v}$ whose values are determined from pertinent sections of the code. The effect of variation in geotechnical properties like plasticity index (PI), over consolidation ratio (OCR), effective stress ( $\left.\sigma^{\prime}\right)$, depth of soil strata over bedrock and variation in impedance contrast ratio (ICR) between soil strata and bedrock are currently not included in the AASHTO code-based site characterization and design spectrum construction processes. This study examined the influence of these geotechnical and site parameters on site amplification factors $\left(\mathrm{F}_{\mathrm{a}}\right.$ and $\left.\mathrm{F}_{\mathrm{v}}\right)$ used for constructing the seismic design spectrum for bridge design.

Site amplification factors in the AASHTO code are based on site conditions and seismicity representative of the western United States [3]. The effect of variation in seismic setting is somewhat taken into account by assigning higher values of site amplification factors for lower design PGA values [4] However, the effect of geological setting characterized by depth and properties of the bedrock as well as variation in the index properties of soil are currently not included. A number of investigators had taken note of the discrepancy related to the geological setting for particular areas [5-13]. Few studies also attempted to analyze the sensitivity of site amplification factors to variability in soil index properties $[14,15]$. This study had attempted to conduct an extensive analysis on the sensitivity of site amplification factors $\left(F_{a}\right.$ and $\left.F_{v}\right)$ to geological variability (strata depth and bedrock properties), geotechnical factors (PI, OCR, $\sigma^{\prime}$ ) and intensity of seismic ground motions for site classes $\mathrm{C}$ and $\mathrm{D}$ in the AASHTO code. The results were analyzed to identify the most influential parameters for various site conditions. The computed site amplification factors were compared with values in the AASHTO bridge design code and potential limitations in the code were identified as the large variability of individual site responses does not appear to be well-captured by a single discrete code value for each site class.

\section{METHODOLOGY}

\section{Background}

AASHTO code classifies site conditions into six categories (A to $\mathrm{F}$ ) based on $\mathrm{V}_{\mathrm{s} 30}$. Refering to Table 1, these site classes are: (a) rock sites (classes $A$ and $B$ ) with $V_{\mathrm{s} 30}$ greater than $1500 \mathrm{~m} / \mathrm{s}$ and $760 \mathrm{~m} / \mathrm{s}$ respectively, (b) soil-rock ( class C) with $360<$ $\mathrm{V}_{\mathrm{s} 30}<760 \mathrm{~m} / \mathrm{s}$, (c) stiff soil (class D) having $\mathrm{V}_{\mathrm{s} 30}$ between 175 and $360 \mathrm{~m} / \mathrm{s}$, (d) soft soil (class E) in which $\mathrm{V}_{\mathrm{s} 30}$ is less than 175 $\mathrm{m} / \mathrm{s}$ and (e) highly organic or highly plastic soft soils (class F) requiring site-specific studies. Table 1 also presents an and those in the European [16], Japanese [17] and Australia - New Zealand [18] design codes. The US and European codes utilize $\mathrm{V}_{\mathrm{s} 30}$ for site classification while the Japanese and AustraliaNew Zealand approximate correspondence between AASHTO 
Table 1: Soil classification in various codes based on shear wave velocity, $V_{\text {s. }}$

\begin{tabular}{|c|c|c|c|c|c|c|c|}
\hline \multicolumn{2}{|c|}{ AASHTO } & \multicolumn{2}{|c|}{ EC 8} & \multicolumn{2}{|c|}{ JRA } & \multicolumn{2}{|c|}{ AS/NZS 1170} \\
\hline Site Class & $\mathrm{V}_{\mathrm{s}}(\mathrm{m} / \mathrm{s})$ & Site Class & $\mathrm{V}_{\mathrm{s}}(\mathrm{m} / \mathrm{s})$ & Site Class & $\mathrm{V}_{\mathrm{s}}(\mathrm{m} / \mathrm{s})$ & Site Class & $\mathrm{V}_{\mathrm{s}}(\mathrm{m} / \mathrm{s})$ \\
\hline $\begin{array}{c}\text { A: } \\
\text { Hard rock }\end{array}$ & $>1500$ & \multirow{2}{*}{$\begin{array}{c}\text { A: } \\
\text { Rock }\end{array}$} & \multirow{2}{*}{$>800$} & \multirow{3}{*}{$\begin{array}{c}\text { SC-I } \\
\left(\mathrm{T}_{\mathrm{G}}<0.2 \mathrm{~s}\right)\end{array}$} & \multirow{3}{*}{$>300$} & $\begin{array}{l}\text { A: Strong } \\
\text { Rock }\end{array}$ & $>1500^{(\mathrm{b})}$ \\
\hline $\begin{array}{c}\text { B: } \\
\text { Rock }\end{array}$ & $760 \sim 1500$ & & & & & \multirow{2}{*}{$\begin{array}{l}\text { B: } \\
\text { Rock }\end{array}$} & \multirow{2}{*}{$360 \sim 1500^{(\mathrm{c})}$} \\
\hline $\begin{array}{c}\text { C: } \\
\text { Soft rock or } \\
\text { Very dense soil }\end{array}$ & $360 \sim 760$ & $\begin{array}{c}\text { B: } \\
\text { Stiff soil } \\
\text { deposits }\end{array}$ & $350 \sim 800$ & & & & \\
\hline $\begin{array}{c}\text { D: } \\
\text { Stiff soil }\end{array}$ & $175 \sim 360$ & $\begin{array}{c}\text { C: } \\
\text { Med. Dense } \\
\text { sand, gravel, } \\
\text { med. stiff } \\
\text { clay }\end{array}$ & $200 \sim 350$ & $\begin{array}{c}\mathrm{SC}-\mathrm{II} \\
\left(\mathrm{T}_{\mathrm{G}}: 0.2-\right. \\
0.6 \mathrm{~s})\end{array}$ & $200 \sim 300^{(a)}$ & $\begin{array}{c}\text { C: Shallow } \\
\text { soil } \\
\left(\mathrm{T}_{\mathrm{G}}<0.6 \mathrm{~s}\right)\end{array}$ & $\begin{array}{l}133 \sim 400 \text { for } \\
\text { cohesive } \\
\text { soils(d) } \\
267 \sim 633 \text { for } \\
\text { cohesionless } \\
\text { soils (d) }\end{array}$ \\
\hline \multirow{2}{*}{$\begin{array}{c}\text { E: } \\
\text { Soft soil }\end{array}$} & \multirow{2}{*}{$<175$} & \multirow{2}{*}{$\begin{array}{c}\text { D: } \\
\text { Loose soil }\end{array}$} & \multirow{2}{*}{$<200$} & \multirow{2}{*}{$\begin{array}{c}\text { SC-III } \\
\left(\mathrm{T}_{\mathrm{G}}>0.6 \mathrm{~s}\right)\end{array}$} & \multirow[t]{2}{*}{$<200^{(a)}$} & $\begin{array}{c}\mathrm{D}: \\
\text { Deep/soft soil } \\
\left(\mathrm{T}_{\mathrm{G}}>0.6 \mathrm{~s}\right)\end{array}$ & $150 \sim 200^{(\mathrm{d})}$ \\
\hline & & & & & & $\begin{array}{c}\text { E: } \\
\text { very soft soil }\end{array}$ & $\mathrm{V}_{\mathrm{s} 10}<150$ \\
\hline
\end{tabular}

(a) Equivalent site class based on time period of soil formation and shear wave velocity [19].

(b) Also requires unconfined compressive strength $>50 \mathrm{MPa}$. Vs range is for $\mathrm{V}_{\mathrm{s} 30 \text {. }}$

(c) Also requires a compressive strength between 1 and $50 \mathrm{MPa}$, intended to eliminate soils from this class, which will make up most of the materials toward the lower end of the velocity range. $\mathrm{Vs}$ range is for $\mathrm{V}_{\mathrm{s} 30}$.

(d) Depends on strata depth, descriptions and geotechnical properties. Maximum depths for Class C are 0-60 m for various categories of cohesive soil, and 0-100m for various cohesionless soils and gravels. Deeper strata are classified as site class D The velocity ranges correspond to the travel-time averaged values across the full soil depth, not averaged to 30m depth [20].

site classes codes employ fundamental period of the strata overlying the bedrock in site classification as well.

Seismic design spectrum for a bridge site is constructed in the AASHTO code based on seismic hazard at the site, which is given in terms of PGA, short $(0.2 \mathrm{~s})$ and long $(1.0 \mathrm{~s})$ period spectral accelerations; $S_{s}$ and $S_{1}$ respectively and site amplification factors, $F_{a}$ and $F_{v}$, which correspond to short and medium periods respectively. $\mathrm{F}_{\mathrm{a}}$ and $\mathrm{F}_{\mathrm{v}}$ in the AASHTO code were developed for geological conditions and seismic setting prevalent in the western United States with the following values: strata depth of $30-40 \mathrm{~m}$, PI of 15 and $\mathrm{V}_{\text {rock }}$ between 760 and $900 \mathrm{~m} / \mathrm{s}$ [3].

This study attempted to investigate the influence of variability in geological and geotechnical parameters on $F_{a}$ and $F_{v}$ by conducting 1-D site response analysis on soil profiles representatives of AASHTO site classes C and D. These site classes were selected because these are the most commonly occurring soil classes which are suitable for both shallow as well as deep foundations and are characterized by a wide variation in $\mathrm{V}_{\mathrm{s} 30}(175-760 \mathrm{~m} / \mathrm{s}), \mathrm{PI}(0-60)$, OCR $(1-10)$ and $\sigma^{\prime}(20-1500 \mathrm{kPa}$ or $0.2-15 \mathrm{~atm})$.

\section{Procedure}

Sensitivity of soil amplification factors to variation in $\mathrm{V}_{\mathrm{s} 30}$, PI, OCR, $\sigma$, depth of soil strata and variation in bedrock shear wave velocity $\left(\mathrm{V}_{\text {rock }}\right)$ was undertaken in this study. Considered values of these parameters are listed in Table 2 . The analysis procedure consisted of the following steps:

\section{Selection of Soil Profiles}

AASHTO site classes $\mathrm{C}$ and $\mathrm{D}$ encompass a wide range of $\mathrm{V}_{\mathrm{s} 30}$ values (i.e. $175-760 \mathrm{~m} / \mathrm{s}$ ). In order to delineate the effect of $\mathrm{V}_{\mathrm{s} 30}$ on seismic site amplification factors, these site classes were further sub-divided into 5 site classes as listed in Table 3. Soil profiles corresponding to the $\mathrm{V}_{\mathrm{s} 30}$ ranges for these five site classes were selected from the literature [21, 22] and are
Table 2: Variation in soil parameters considered in the study.

\begin{tabular}{|c|c|}
\hline Parameter & Values \\
\hline \multirow{5}{*}{$\mathrm{V}_{\mathrm{s} 30}(\mathrm{~m} / \mathrm{s})$} & 600 ( $\left.\mathrm{C}_{\text {h high }}\right)$ \\
\hline & 475 (C_avg) \\
\hline & 350 (D_high) \\
\hline & 275 (D_avg) \\
\hline & 175 (D_low) \\
\hline PI & $0,15,60$ \\
\hline$\sigma^{\prime}$ (atm) & 2,4 \\
\hline $\begin{array}{c}\text { Strata } \\
\text { depth }(\mathrm{m})\end{array}$ & 40,110 \\
\hline OCR & 1 \\
\hline $\mathrm{V}_{\text {rock }}(\mathrm{m} / \mathrm{s})$ & $\begin{array}{c}600,760,1350, \\
2251,3353\end{array}$ \\
\hline
\end{tabular}

depicted in Fig. 1 for $40 \mathrm{~m}$ and $110 \mathrm{~m}$ deep strata. These physically-realistic soil profiles were generated based on statistical study of 858 real soil profiles from Japan, western North America and France in [21] while [22] used a maximumlikelihood procedure on 557 soil profiles to statistically generate shear wave velocity profiles corresponding to Geomatrix and US Geological Survey (USGS) site classes.

The profiles used in this study are representative of soil strata with gradually increasing shear wave velocity with depth. Other

Table 3: Soil profiles and their mechanical properties.

\begin{tabular}{|c|c|c|c|c|c|c|}
\hline \begin{tabular}{|c|} 
AASHTO \\
Site \\
Class
\end{tabular} & $\begin{array}{c}\text { Soil } \\
\text { Profile }\end{array}$ & $\begin{array}{l}V_{\mathrm{s30}} \\
(\mathrm{m} / \mathrm{s})\end{array}$ & $\underset{\left(\mathbf{k g} / \mathbf{m}^{3}\right)}{\rho}$ & $v$ & $\begin{array}{c}\mathbf{G} \\
(\mathbf{M P a})\end{array}$ & $\begin{array}{c}\beta \\
(\%)\end{array}$ \\
\hline \multirow{2}{*}{$\mathrm{C}$} & C_high & 600 & 2060 & 0.35 & 741 & 3 \\
\hline & C_avg & 475 & 2020 & 0.35 & 456 & 4 \\
\hline \multirow{3}{*}{ D } & D_high & 350 & 1980 & 0.40 & 243 & 5 \\
\hline & D_avg & 275 & 1900 & 0.40 & 144 & 7 \\
\hline & D_low & 175 & 1850 & 0.42 & 57 & 8 \\
\hline
\end{tabular}




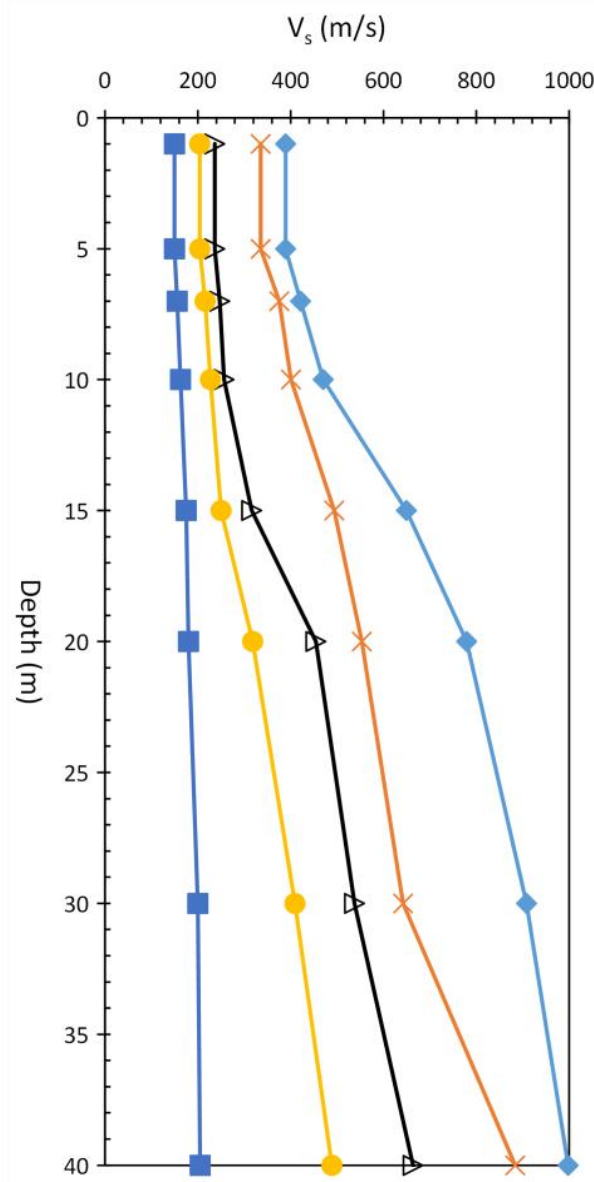

(a)
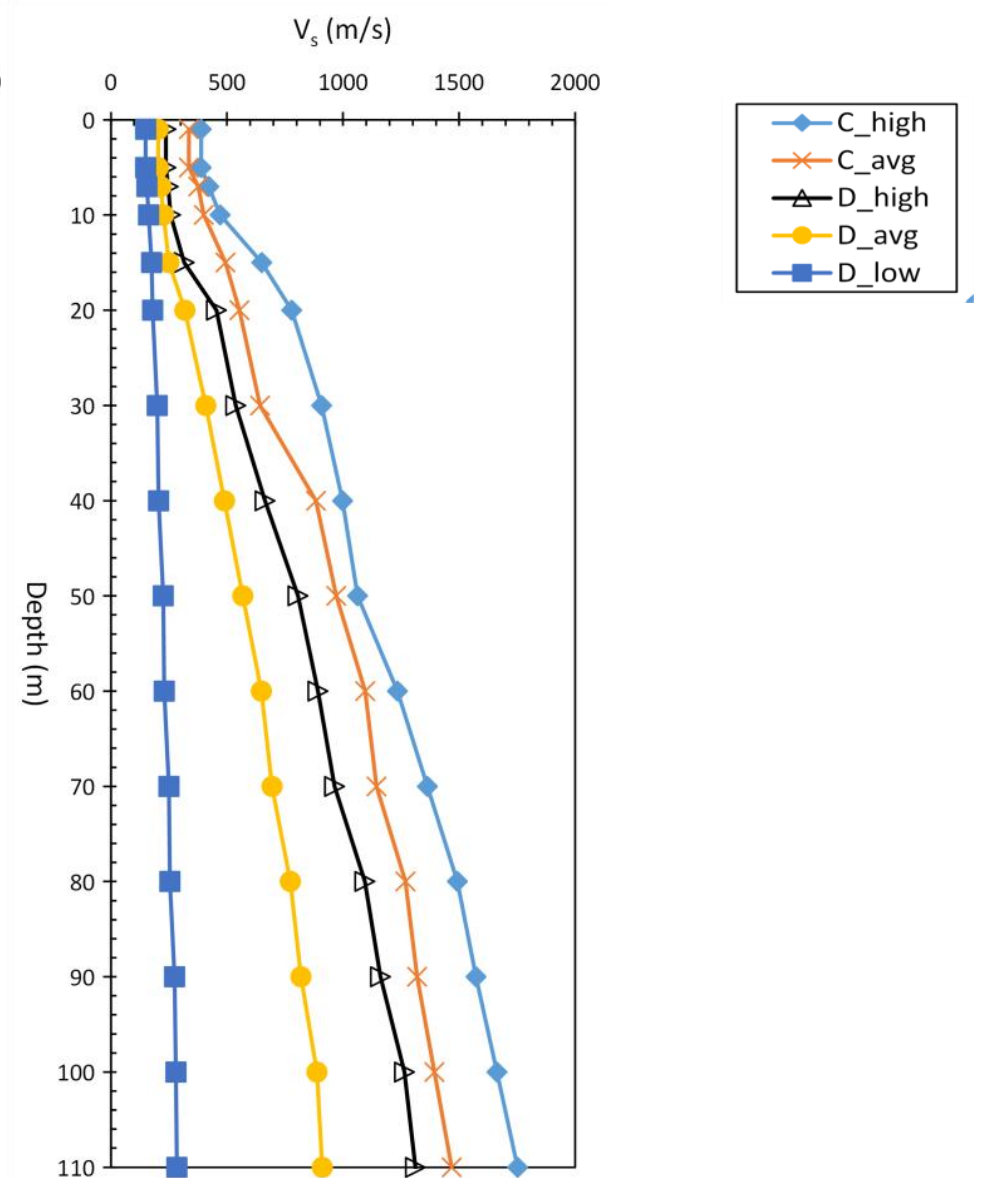

(b)

Figure 1: Shear wave velocity profile for various site classes (after [21, 22]). (a) 40m deep strata and (b) 110m deep strata.

permutations of soil profiles with sharp differences in layer properties $\left(V_{s 30}\right.$, unit weight, PI etc.) were not considered in this study. Mechanical properties, i.e. $V_{\mathrm{s} 30}$, density $(\rho)$, Poisson's ratio $(v)$, shear modulus $(\mathrm{G})$ and damping ratio $(\beta)$, of the soil profiles are listed in Table $3 . \mathrm{V}_{\mathrm{s}}$ values in some layers of these profiles were scaled to match the target $\mathrm{V}_{\mathrm{s} 30}$ for each site class. Refer to [23] for details.

\section{Selection of Bedrock Parameters}

In this study, shear wave velocity of the rock mass $\left(\mathrm{V}_{\text {rock }}\right)$ was chosen as the defining parameter for rock classification. South African Council on Scientific and Industrial Research (CSIR) classification for rocks [24] was used to classify the bedrock into classes I to $\mathrm{V}$ as listed in Table 4. According to this classification, quality of rock decreases from class I to $\mathrm{V}$ as
$V_{\text {rock }}$ decreases from $3353 \mathrm{~m} / \mathrm{s}$ for class I rock to $600 \mathrm{~m} / \mathrm{s}$ for class $\mathrm{V}$ rock. Mechanical properties, i.e. $\mathrm{V}_{\text {rock}}, \rho, v, \mathrm{G}$ and allowable bearing pressure $\left(\mathrm{q}_{\mathrm{a}}\right)$, of the bedrock are listed in Table 4. Damping ratio of the bedrock ( $\left.\beta_{\text {rock }}\right)$ was taken as $1 \%$ [25].

\section{Variation in Soil Geotechnical Parameters}

Table 2 summarizes the variations in soil geotechnical parameters, i.e. PI, OCR, $\sigma$ ', strata depth and $\mathrm{V}_{\text {rock }}$ used in the study. The PI values chosen in the study (i.e. 0, 15 and 60) correspond to the generally accepted limits for non-plastic (i.e. sand), medium plastic and highly plastic soils [26]. A constant value of OCR $(=1)$ was adopted for all soil profiles based on the recommendations of [27].

Table 4: Rock profiles and their mechanical properties.

\begin{tabular}{|c|c|c|c|c|c|c|c|}
\hline $\begin{array}{l}\text { AASHTO } \\
\text { Site Class }\end{array}$ & $\begin{array}{l}\text { Rock } \\
\text { Class }\end{array}$ & $\begin{array}{c}\text { Rock } \\
\text { Description }\end{array}$ & $\begin{array}{l}V_{\text {rock }} \\
(\mathrm{m} / \mathrm{s})\end{array}$ & $\begin{array}{c}\rho \\
\left(\mathrm{kg} / \mathrm{m}^{3}\right)\end{array}$ & $v$ & $\begin{array}{c}\mathbf{G} \\
(\mathbf{G P a})\end{array}$ & $\begin{array}{c}\mathbf{q a} \\
\left(\mathbf{k N} / \mathbf{m}^{2}\right)\end{array}$ \\
\hline \multirow{2}{*}{ A } & I & Very good & 3353 & 2920 & 0.15 & 32.60 & 3816 \\
\hline & II & Good & 2251 & 2610 & 0.20 & 13.18 & 2051 \\
\hline \multirow[t]{2}{*}{ B } & III & Fair & 1350 & 2320 & 0.25 & 4.00 & 839 \\
\hline & IV & Poor & 760 & 2090 & 0.30 & 1.22 & 385 \\
\hline $\mathrm{C}$ & $\mathrm{V}$ & Very Poor & 600 & 2060 & 0.35 & 0.74 & 215 \\
\hline
\end{tabular}



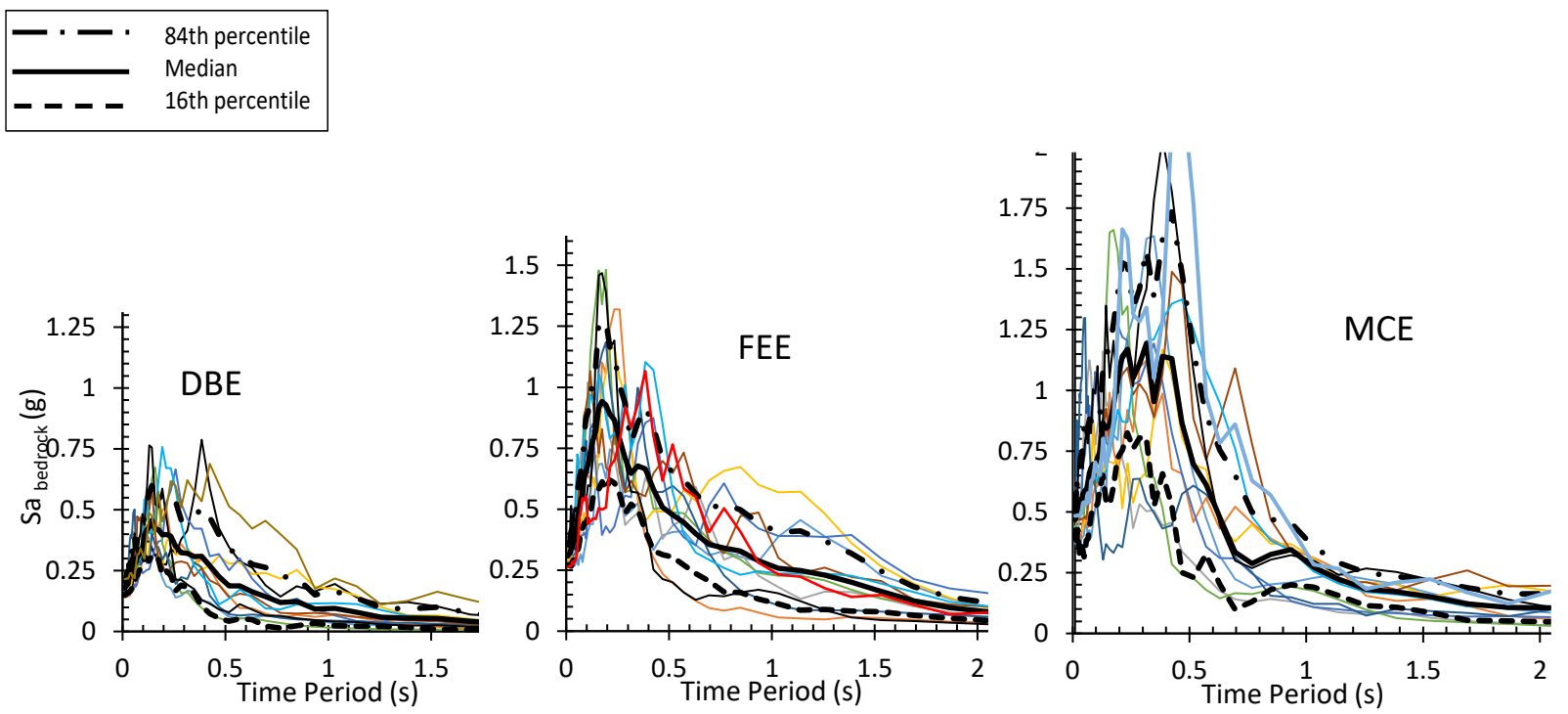

Figure 2: Acceleration response spectra of the used strong motions.

Confining pressure of soil layers increases with depth when density of the strata is assumed to stay constant. However, only two values of effective stress, $\sigma^{\prime},(2 \mathrm{~atm}$ for sands and $4 \mathrm{~atm}$ for clays) were used in the study. This simplification was based on the work of [27] who compared modulus reduction and damping (MRD) curves proposed by [28 - 30] and demonstrated that MRD curves of $[28,29]$ provided better fit for engineering applications than [30]. MRD curves of [29] do not account for the confining pressure effect, while it is captured in curves of [28]. In the current study, confining pressure values that matched the MRD curves of [29] and the median value of curves of [28] were used (i.e. 2 atm for sands and $4 \mathrm{~atm}$ for clays). This decision was also supported by the work of [8] who showed that variability in MRD curves did not significantly affect the site response variability in comparison to other factors. Restricting the range of $\sigma^{\prime}$ to two values in defining the MRD curves thus allowed reduction of the number of variables in the study without significantly affecting the final conclusions.

\section{Selection of Seismic Ground Motions}

The selected seismic ground motions were representative of typical far-field records that were recorded more than $10 \mathrm{~km}$ away from the epicenter [31]. Seismic ground motions were sorted into three groups based on the median PGA values. Groups 1,2 and 3 had median PGA values of $0.17 \mathrm{~g}, 0.31 \mathrm{~g}$ and $0.43 \mathrm{~g}$ respectively. These seismic ground motion groups approximately correspond to design basis earthquake (DBE), functional evaluation earthquake (FEE) and maximum considered earthquake (MCE) for a site with design PGA of $0.2 \mathrm{~g}$.

It is required that in order to use the mean (or median) response as the design value, a ground motion suite consisting of seven or more different records should be used in the analysis for a single hazard level $[16,32]$. If fewer records are used, then the design value is defined as the maximum observed response and mean value cannot be used. Use of eleven seismic records is recommended by [33] so that the mean response parameters are within $30 \%$ and $70 \%$ confidence levels. Therefore, a suite of eleven ground motions for each of the three levels of earthquake intensities were selected from the literature [34-36] to perform one-dimensional non-linear seismic site response analysis. The seismic ground motions were downloaded from PEER strong motion database website [37].
Fig. 2 depicts the acceleration response spectra for the three seismic intensity levels, while Table 5 lists the salient seismic event details of the used seismic ground motions. Some ground motions were scaled to match the targeted median value and such values are identified in Table 5 with a footnote.

Shear wave velocity of the sites in the selected ground motion set shown in Table 5 varied between $600 \mathrm{~m} / \mathrm{s}$ and $1428 \mathrm{~m} / \mathrm{s}$ with an average value of $747 \mathrm{~m} / \mathrm{s}$. It is understood that the bedrock $\mathrm{V}_{\mathrm{s}}$ used in the study varied between $760 \mathrm{~m} / \mathrm{s}$ and $3353 \mathrm{~m} / \mathrm{s}$ and $\mathrm{V}_{\mathrm{s}}$ of the used input motions should ideally match these values. However, non-availability of recorded ground motions on very hard rock sites that also satisfy the far-field fault distance criterion $(>=10 \mathrm{~km})$, PGA variation from $0.1 \mathrm{~g}$ to $0.5 \mathrm{~g}$ and the required number of the ground motions (minimum 7 and preferably 11 to use the median response value as representative of the actual response with statistical confidence) precluded this effort. Additionally, the author did not want to scale very weak motions recorded on hard rock sites to match PGA values targeted in the study.

This is the reason that the suite of ground motions presented in Table 5 is representative of 'weak to hard rock' motions instead of 'hard rock' conditions $\left(\mathrm{V}_{\mathrm{s}}>760 \mathrm{~m} / \mathrm{s}\right)$. Nonetheless, average $\mathrm{V}_{\mathrm{s}}$ of the suite of ground motions $(747 \mathrm{~m} / \mathrm{s})$ is very close to the threshold value of $760 \mathrm{~m} / \mathrm{s}$ assigned to $V_{s}$ of seismic bedrock. Therefore, use of the ground motion data set of Table 5 should provide values of the response parameters sufficiently close to the 'real' values corresponding to the data set recorded on 'hard rock'. Additionally, it has been demonstrated that use of input ground motions with different frequency content that resulted from recordings made on soil or rock sites, did not cause significant discrepancy in the response quantities [38]

\section{1-D Seismic Site Response Analysis}

More than 3950 1-D seismic site response analysis were carried out for the 33 seismic ground motions, 5 site classes, 3 values of PI, $4 \mathrm{~V}_{\text {rock }}$ values and 2 strata depths included in this study. 1-D seismic site response analysis was carried out using the STRATA software [25]. STRATA is capable of performing a 1-D equivalent-linear seismic site response analysis of the soil column in the time domain while utilizing strain dependent nonlinear MRD curves from multiple references. This study used MRD curves of [28] for reasons mentioned earlier. Fig. 3 depicts the used MRD curves for the site classes included in the study (i.e. AASHTO C and D). 
Table 5: Seismic ground motions used in the study.

\begin{tabular}{|c|c|c|c|c|c|c|}
\hline \multicolumn{2}{|c|}{$\begin{array}{l}\text { EQ } \\
\text { Record } \\
\text { ID }\end{array}$} & \multirow{2}{*}{$\begin{array}{l}\text { Seismic event and station details } \\
\text { San Fernando, 2/9/1971, Lake Hughes \#9, } 291\end{array}$} & \multirow{2}{*}{$\begin{array}{c}\text { Magnitude } \\
6.61 \\
\end{array}$} & \multirow{2}{*}{$\begin{array}{c}\text { PGA (g) } \\
0.14 \\
\end{array}$} & \multirow{2}{*}{$\begin{array}{c}\begin{array}{c}\text { Fault } \\
\text { distance } \\
(\mathbf{k m})\end{array} \\
17 \\
\end{array}$} & \multirow{2}{*}{$\begin{array}{r}\mathbf{V}_{\mathbf{s}} \\
(\mathbf{m} / \mathbf{s}) \\
671 \\
\end{array}$} \\
\hline \multirow{11}{*}{ 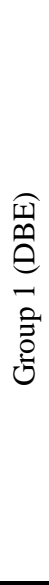 } & 1 & & & & & \\
\hline & 2 & Kozani Greece-01, 5/13/1995, Kozani, T & 6.40 & 0.14 & 14 & 650 \\
\hline & 3 & Northridge-01, 1/17/1994, Vasquez Rocks Park, 0 & 6.69 & 0.15 & 24 & 996 \\
\hline & 4 & Northridge-01, 1/17/1994, LA - Wonderland Ave, 185 & 6.69 & 0.16 & 15 & 1223 \\
\hline & 5 & Duzce Turkey, 11/12/1999, Lamont 531, N & 7.14 & 0.16 & 23 & 638 \\
\hline & 6 & Lytle Creek, 9/12/1970, Devil's Canyon, 90 & 5.33 & 0.17 & 18 & 667 \\
\hline & 7 & San Fernando, 2/9/1971, Lake Hughes \#9, 21 & 6.61 & 0.17 & 26 & 671 \\
\hline & 8 & San Fernando, 2/9/1971, Lake Hughes \#4, 111 & 6.61 & 0.2 & 19 & 600 \\
\hline & 9 & Kozani Greece-01, 5/13/1995, Kozani, L & 6.40 & 0.21 & 14 & 650 \\
\hline & 10 & San Fernando, 2/9/1971, Santa Anita Dam, 273 & 6.61 & 0.22 & 31 & 667 \\
\hline & 11 & Northridge-01, 1/17/1994, LA - Chalon Rd, 70 & 6.69 & 0.22 & 20 & 740 \\
\hline \multirow{11}{*}{ 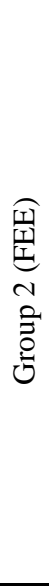 } & 12 & Northridge-01, 1/17/1994, LA 00, 180 & 6.69 & 0.26 & 19 & 706 \\
\hline & 13 & Hector Mine, 10/16/1999, Hector, 0 & 7.13 & 0.27 & 12 & 726 \\
\hline & 14 & San Fernando, 2/9/1971, Lake Hughes \#12, 291 & 6.61 & 0.28 & 19 & 602 \\
\hline & 15 & Loma Prieta, 10/18/1989, San Jose - Santa Teresa Hills, 225 & 6.93 & 0.28 & 15 & 672 \\
\hline & 16 & Morgan Hill, 4/24/1984, Gilroy Array \#6, 90 & 6.19 & 0.29 & 10 & 663 \\
\hline & 17 & Kobe, Japan, 1/16/1995, Kobe University, 90 & 6.90 & $0.31[0.29]^{\mathrm{a}}$ & 16 & 828 \\
\hline & 18 & Tabas Iran, 9/16/1978, Dayhook, L & 7.35 & 0.32 & 14 & 660 \\
\hline & 19 & Loma Prieta, 10/18/1989, Gilroy - Gavilan Coll., 337 & 6.93 & 0.33 & 10 & 730 \\
\hline & 20 & Loma Prieta, 10/18/1989, San Jose - Santa Teresa Hills, 315 & 6.93 & $0.33[0.26]^{\mathrm{a}}$ & 15 & 672 \\
\hline & 21 & Loma Prieta, 10/18/1989, Gilroy - Gavilan Coll., 67 & 6.93 & 0.36 & 10 & 730 \\
\hline & 22 & San Fernando, 2/9/1971, Lake Hughes \#12, 21 & 6.61 & 0.38 & 19 & 602 \\
\hline \multirow{11}{*}{ 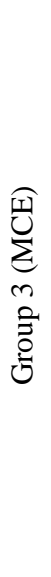 } & 23 & Coyote Lake, 8/6/1979, Gilroy Array \# 6, 320 & 6.93 & $0.37[0.42]^{\mathrm{a}}$ & 18 & 714 \\
\hline & 24 & Northridge-01, 1/17/1994, LA 00, 270 & 6.69 & 0.38 & 19 & 706 \\
\hline & 25 & Loma Prieta, 10/18/1989, UCSC, 0 & 6.93 & $0.39[0.31]^{\mathrm{a}}$ & 18 & 714 \\
\hline & 26 & Tabas Iran, 9/16/1978, Dayhook, T & 7.35 & 0.41 & 14 & 660 \\
\hline & 27 & Loma Prieta, 10/18/1989, Gilroy Array \#1, 0 & 6.93 & 0.42 & 10 & 1428 \\
\hline & 28 & San Fernando, 2/9/1971, Lake Hughes \#12, 21 & 6.61 & $0.43[0.38]^{\mathrm{a}}$ & 19 & 602 \\
\hline & 29 & Manji, Iran, 6/20/1990, Abbar L & 7.37 & $0.46[0.51]^{\mathrm{a}}$ & 13 & 724 \\
\hline & 30 & Kobe Japan, 1/16/1995, Nishi-Akashi, 90 & 6.90 & 0.46 & 9 & 609 \\
\hline & 31 & Chi-Chi Taiwan, 9/20/1999, TCU045, E & 7.62 & 0.47 & 26 & 705 \\
\hline & 32 & Loma Prieta, 10/18/1989, Gilroy Array \#1, 90 & 6.93 & 0.48 & 10 & 1428 \\
\hline & 33 & Kobe Japan, 1/16/1995, Nishi-Akashi, 0 & 6.90 & 0.48 & 9 & 609 \\
\hline
\end{tabular}

a recorded]

\section{Site Amplification Factors and Sensitivity Analysis}

Site amplification factors for the short period $\left(\mathrm{F}_{\mathrm{a}}\right)$ and medium period $\left(F_{v}\right)$ ranges were computed from the ratio of spectral acceleration between the surface and bedrock locations. A detailed analysis was carried out to find impact of variation in PI, soil strata depth above the bedrock and variation in bedrock properties on soil amplification factors for various site classes and EQ intensity levels. These steps are explained in the following sections.

\section{Comparison with AASHTO Code}

The computed soil amplification factors $\left(F_{a}\right.$ and $\left.F_{v}\right)$ were compared with the AASHTO code values and conclusion were drawn in the last section.

\section{COMPUTATION OF SOIL AMPLIFICATION FACTORS}

Seismic design spectrum is constructed using 2 soil amplification factors (i.e. $F_{a}$ and $F_{v}$ ) in the AASHTO code [2]. $F_{a}$ and $F_{v}$ and represent soil amplification in the short period $(0$ 

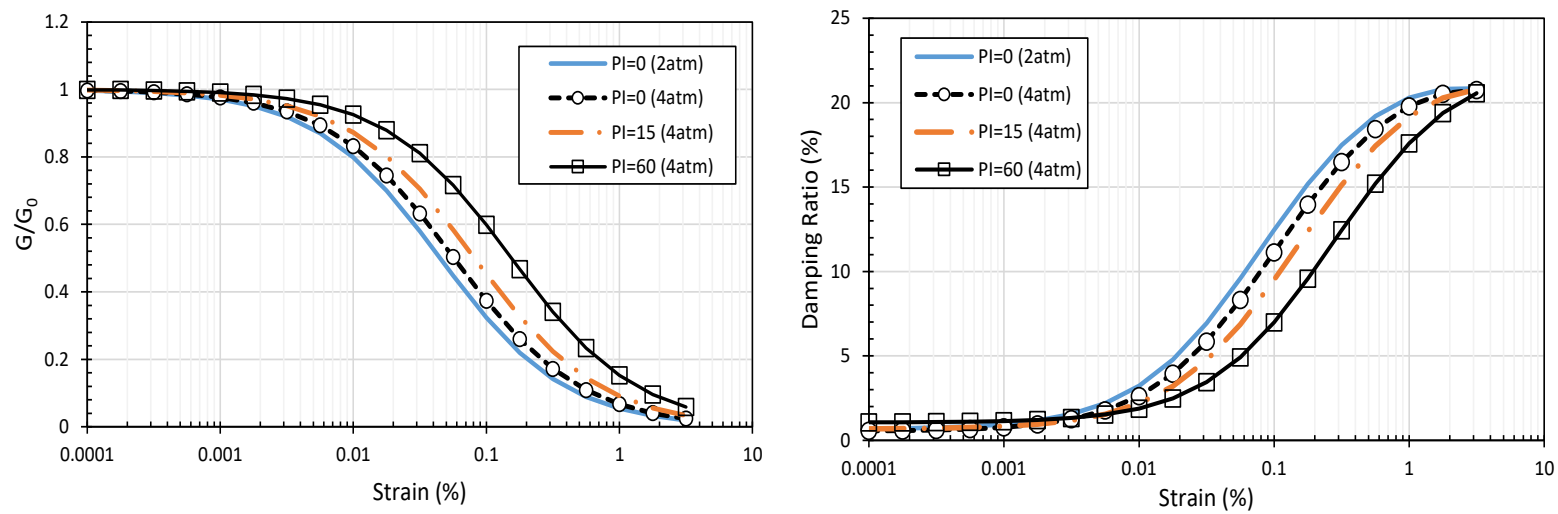

Figure 3: Modulus reduction and damping curves for soils in site classes $C$ and $D$.

$-0.4 \mathrm{~s})$ and the medium period $(0.5-2.0 \mathrm{~s})$ ranges respectively. Researchers have proposed a variety of approaches to compute these amplification factors [39-42]. However, in the current study, the method proposed by [43] and modified by [44] was used to compute $F_{a}$ and $F_{v}$ values given by the following expressions:

$$
F_{a}=\frac{1}{0.4} \int_{0.1}^{0.5} \frac{R S_{\text {soil }}(T)}{R S_{\text {rock }}(T)} d T
$$
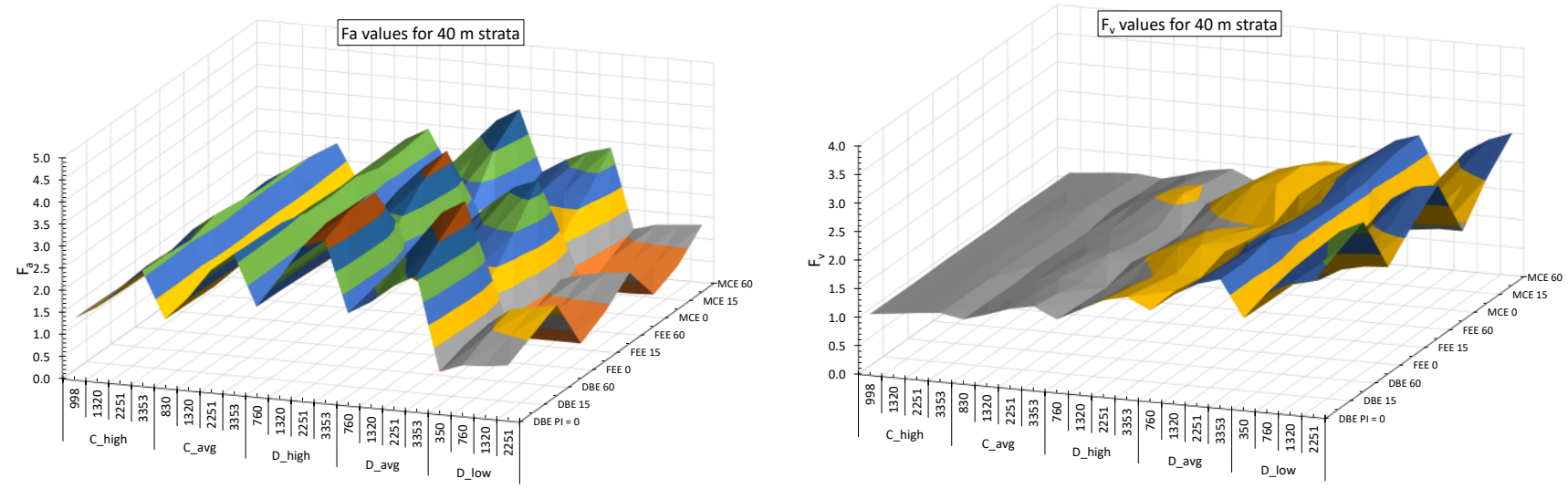

Figure 4: Distribution of $F_{a}$ and $F_{v}$ values for $40 m$ deep strata for various soil classes, $V_{\text {rock, }}$ earthquake intensity and $P I$.
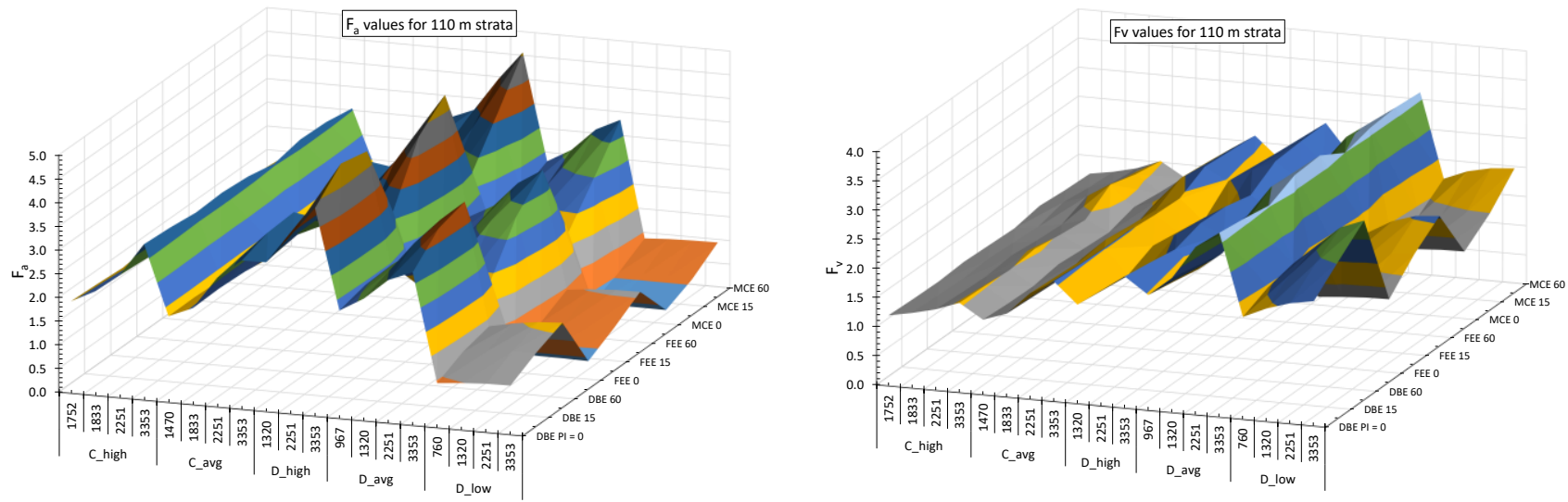

Note: Numbers on the $X$-axis represent $V_{\text {rock. }}$

Figure 5: Distribution of $F_{a}$ and $F_{v}$ values for $110 \mathrm{~m}$ deep strata for various soil classes, $V_{\text {rock, }}$ earthquake intensity and PI. 
Figs. 4 and 5 present variation in the values of $F_{a}$ and $F_{v}$ for the five site classes as a function of three levels of seismic intensity, $\mathrm{PI}$ and $\mathrm{V}_{\text {rock }}$ for $40 \mathrm{~m}$ and $110 \mathrm{~m}$ deep strata respectively. It can be observed that $F_{a}$ and $F_{v}$ values showed considerable variation with respect to site class, $\mathrm{V}_{\text {rock}}, \mathrm{PGA}$ and variation in PI. Influence of each of these parameters is discussed in the following section.

\section{SENSITIVITY ANALYSIS FOR SOIL AMPLIFICATION FACTORS}

This section analyses the sensitivity of soil amplification factors $\left(F_{a}\right.$ and $F_{v}$ ) with respect to: (i) PI, (ii) $V_{\text {rock, }}$ (iii) earthquake intensity, (iv) strata depth and (v) site classification.

In order to conduct this sensitivity analysis, the results shown in Figs. 4 and 5 were desegregated in Figs. 6 and 7 for $F_{a}$ and $F_{v}$ respectively. Figs. 6 and 7 present variation in $F_{a}$ and $F_{v}$ for the three considered levels of earthquake intensity respectively.
The amplification factors are presented side-by-side for two depths of strata for direct comparison. Code based values of $F_{a}$ and $F_{v}$ are also marked in these figures. Discussion on sensitivity of soil amplification factors for the above-mentioned parameters is presented below.

\section{Effect of PI}

It is well understood that soils with different PI values exhibit significantly varying shear stress-strain and damping behavior with increasing seismic acceleration [28 - 30]. However, the AASHTO code considers only $\mathrm{V}_{\mathrm{s} 30}$ values while assigning site amplification factors. Therefore, soil index properties are not taken into account while selecting the values of these parameters despite the fact that soils with vastly different index properties can have the same $\mathrm{V}_{\mathrm{s} 30}$.

The effect of variation in PI on soil amplification factors $\left(F_{a} \&\right.$ $F_{v}$ ) is examined by computing the percent difference in these
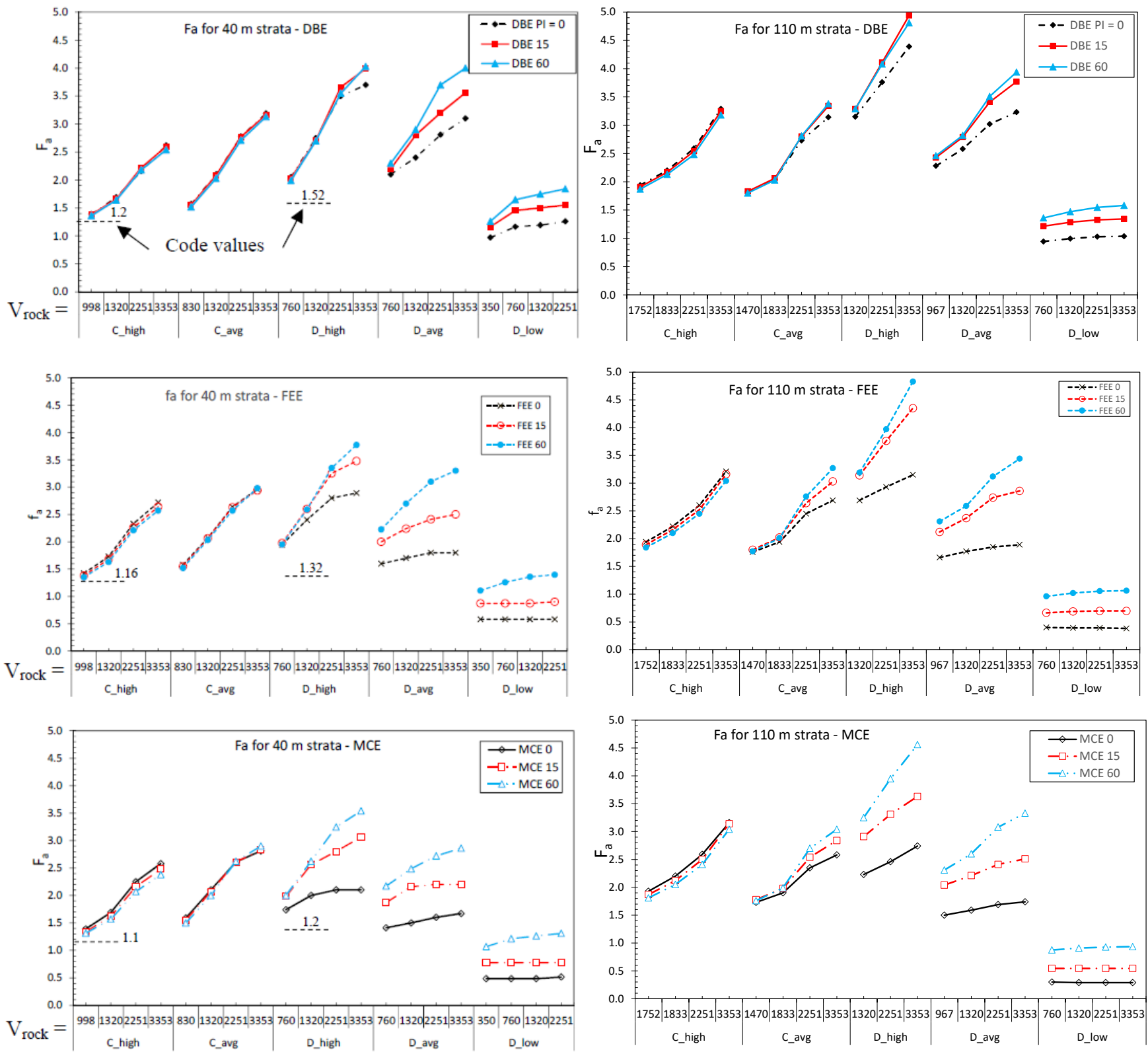

Figure 6: Influence of PI and $V_{\text {rock }}$ on short period amplification factor $\left(F_{a}\right)$ for various soil profiles of $40 \mathrm{~m}$ and $110 \mathrm{~m}$ deep strata with earthquake intensity. 
parameters for a particular analysis case of strata depth, earthquake intensity, site classification and $V_{\text {rock. The following }}$ expression was used to compute the difference in which $\mathrm{Fa}$ is taken as the example parameter:

$\%$ diff.due to PI variation $=\frac{\text { max.diff.in } F \text { a for } 3 \text { PI values }}{\text { avg.Fa for } 3 \text { PI values }}$

Fig. 8 presents the variation of this difference for $F_{a}$ and $F_{v}$ values for $40 \mathrm{~m}$ and $110 \mathrm{~m}$ strata. It was noted that the difference in $\mathrm{F}_{\mathrm{a}}$ due to variation in PI was less than $10 \%$ for site class $C_{-}$high for both strata depths for all values of $\mathrm{V}_{\text {rock. }}$ This variation was less than $10 \%$ for all cases in site class C_avg for $40 \mathrm{~m}$ deep strata and for only three cases of $110 \mathrm{~m}$ strata, its value was slightly more than $20 \%$. This means that variation in PI can be disregarded for computing $\mathrm{Fa}_{\mathrm{a}}$ for site classes C_high and $\mathrm{C}_{-}$avg for both strata depths.

However, the impact of variation in PI on $\mathrm{F}_{\mathrm{a}}$ values was very pronounced (20\% to more than $100 \%$ ) for site classes D_high,
D_avg and D_low for all three levels of earthquake intensities except for DBE level earthquake in site class D_high where the maximum difference was less than $20 \%$ for both strata depths. This implies that neglecting the influence of PI for site classes D_high, D_avg and D_low could lead to significant under/overestimation of true $F_{a}$ values. This deviation increased with decreasing $\mathrm{V}_{\mathrm{s} 30}$ of strata and increasing level of earthquake intensity.

Observations related to variation in $\mathrm{F}_{\mathrm{v}}$ are slightly different than those mentioned for $F_{a}$ and are depicted in Fig. 8(b). The variation in $\mathrm{F}_{\mathrm{v}}$ for site classes $\mathrm{C} \_$high and $\mathrm{C} \_$avg was more than that observed for $F_{a}$ but the value was less than $20 \%$. For site classes D_high and D_avg, the maximum difference was slightly more than $20 \%$ that was less than half the difference for $F_{a}$ values. $F_{v}$ values in site class D_low were affected the most by the PI variation as the maximum difference was more than $60 \%$ for both strata depths. However, this difference was almost half that was noted for $F_{a}$ values.
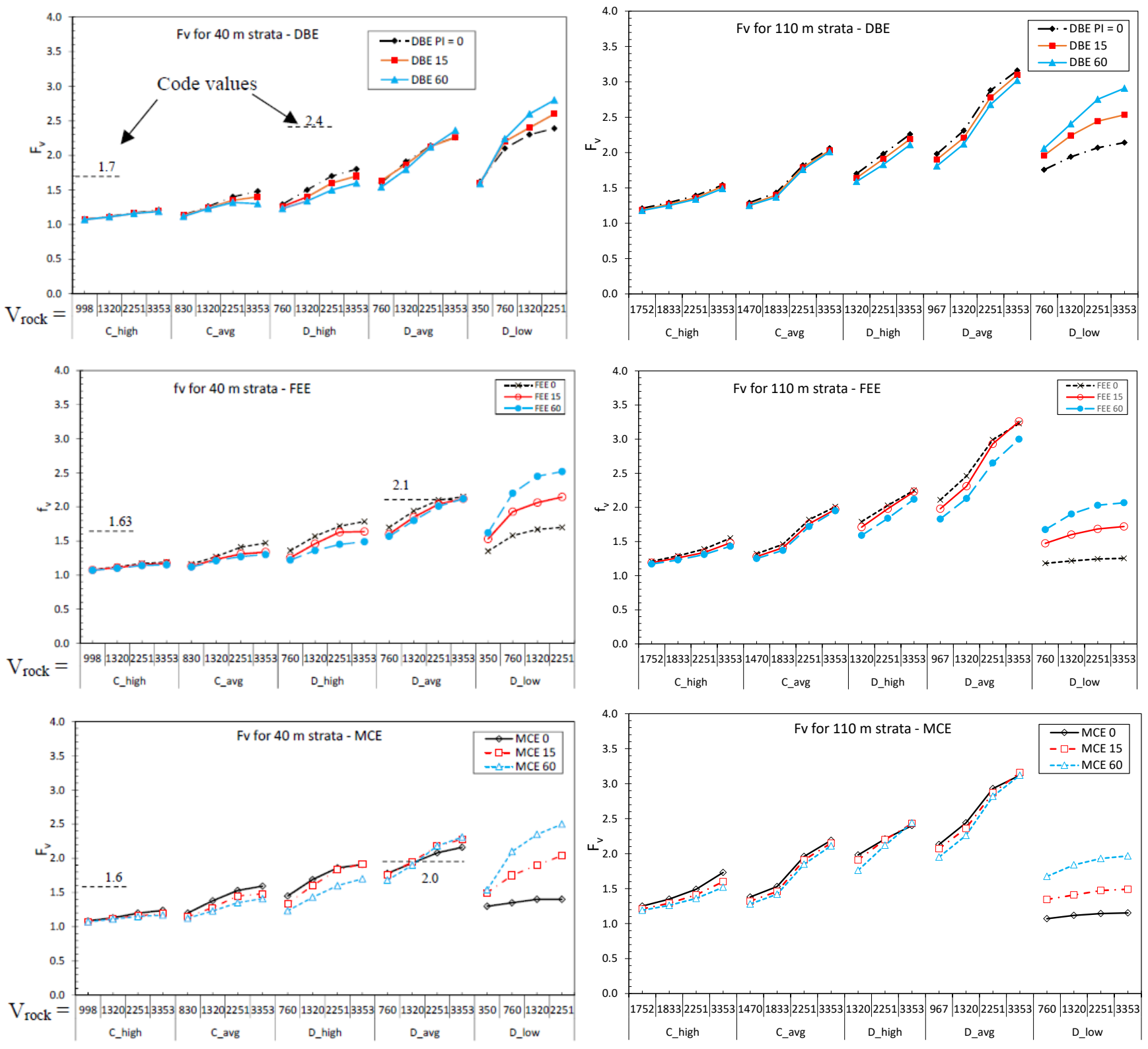

Figure 7: Influence of PI and $V_{\text {rock }}$ on medium period amplification factor $\left(F_{v}\right)$ for various soil profiles of $40 \mathrm{~m}$ and $110 \mathrm{~m}$ deep strata with earthquake intensity. 
In conclusion, it is noted that $\mathrm{F}_{\mathrm{a}}$ values were affected more than $F_{v}$ values due to variation in PI. The effect of PI variation on $F_{a}$ and $F_{v}$ was negligible to low for site classes $C_{-}$high and $C_{-}$avg. However, for site classes D_high, D_avg and D_low, the effect of PI variation on $\mathrm{F}_{\mathrm{a}}$ was moderate to high and should not be neglected. Similarly, this effect was low to moderate for $F_{v}$ values in site classes D_high and D_avg while it was high for site class D_low.

\section{Effect of $V_{\text {rock }}$}

It was observed in Fig. 6 that $\mathrm{F}_{\mathrm{a}}$ values showed an increasing trend with increasing value of $\mathrm{V}_{\text {rock }}$ for all site classes except D_low. Similar examination of Fig. 7 revealed that $F_{v}$ values exhibited the same trend for all site classes except $C_{-}$high. This strong correlation between $V_{\text {rock }}$ and amplification factors ( $F_{a}$ and $\mathrm{F}_{\mathrm{v}}$ ) has its theoretical background in the elastic wave theory. It has been shown that the maximum amplification corresponding to resonance in shear in a soil layer overlying a rock occurs approximately at the fundamental frequency of the soil layer and is approximately given by the following expression [46]:

max. amplification $\approx \frac{1}{\left(\frac{1}{I C R}\right)+\left(\frac{\pi}{2}\right) \beta}$

In this equation, ICR is the impedance contrast ratio defined as: $I C R=\frac{\gamma_{R} V_{S R}}{\gamma_{S} V_{S S}}$, where $\gamma$ is the unit weight, $V_{s}$ is the shear wave velocity and subscripts $R$ and $S$ refers to parameters of the bedrock and the soil layer above it respectively. Whereas, $\beta$ is the damping ratio of the soil layer.

For the analysis cases investigated in this study, ICR varied between 1 and 4 for site class $C$ soils and between 1 and 18 for site class D soils for $110 \mathrm{~m}$ deep strata, while it was between 1 and 7 for type $\mathrm{C}$ soils and between 1 and 16 for type D soils respectively for $40 \mathrm{~m}$ soil profiles [23].

Fig. 9 depicts the relationship between ICR and amplification factor $\left(\mathrm{F}_{\mathrm{a}}\right.$ and $\left.\mathrm{F}_{\mathrm{v}}\right)$ for $40 \mathrm{~m}$ deep strata. Despite the scatter in the data points, a clear trend of increasing $F_{a}$ and $F_{v}$ values can be noted with increasing ICR. The coefficient of determination $\left(\mathrm{R}^{2}\right)$ had a value of 0.52 and 0.49 for $F_{a}$ and $F_{v}$ respectively, whereas, the coefficient of correlation (R) had a value of \pm 0.72 and \pm 0.70 for $F_{a}$ and $F_{v}$ respectively. As $R$-value is in between 0.5 and 0.8 , therefore a moderate correlation exist between $F_{a}$ and $F_{v}$ with respect to ICR [47]. Amplification given by Eq. (4) for $\beta=2 \%$ and $20 \%$ are also plotted in Fig. 9(a) to provide a comparison with the theoretical expression.

The decreasing trend for $\mathrm{F}_{\mathrm{a}}$ values for site class D_low in Fig. 6 was due to the dominant period of the soil strata having its peak outside the interval for which $\mathrm{F}_{\mathrm{a}}$ was computed. Similarly, $F_{v}$ values in Fig. 7 showed a weak correlation with $V_{\text {rock }}$ for site class $\mathrm{C}$, which was due to the natural period of the strata being outside the interval over which $F_{v}$ was computed. However, $F_{v}$ values for soils D_avg and D_low exhibited a relatively stronger correlation with $\mathrm{V}_{\text {rock }}$ as the natural period of the strata was within the interval over which $\mathrm{F}_{\mathrm{v}}$ was calculated.

\section{Effect of Earthquake Intensity}

Figs. 10 and 11 depicts the relationship between $F_{a}$ and $F_{v}$ with three levels of earthquake intensity (i.e. DBE, FEE and MCE) respectively for $40 \mathrm{~m}$ strata for various $V_{\text {rock }}$ values. Relationships for $110 \mathrm{~m}$ strata are similar and are not included herein. The following observations were made.
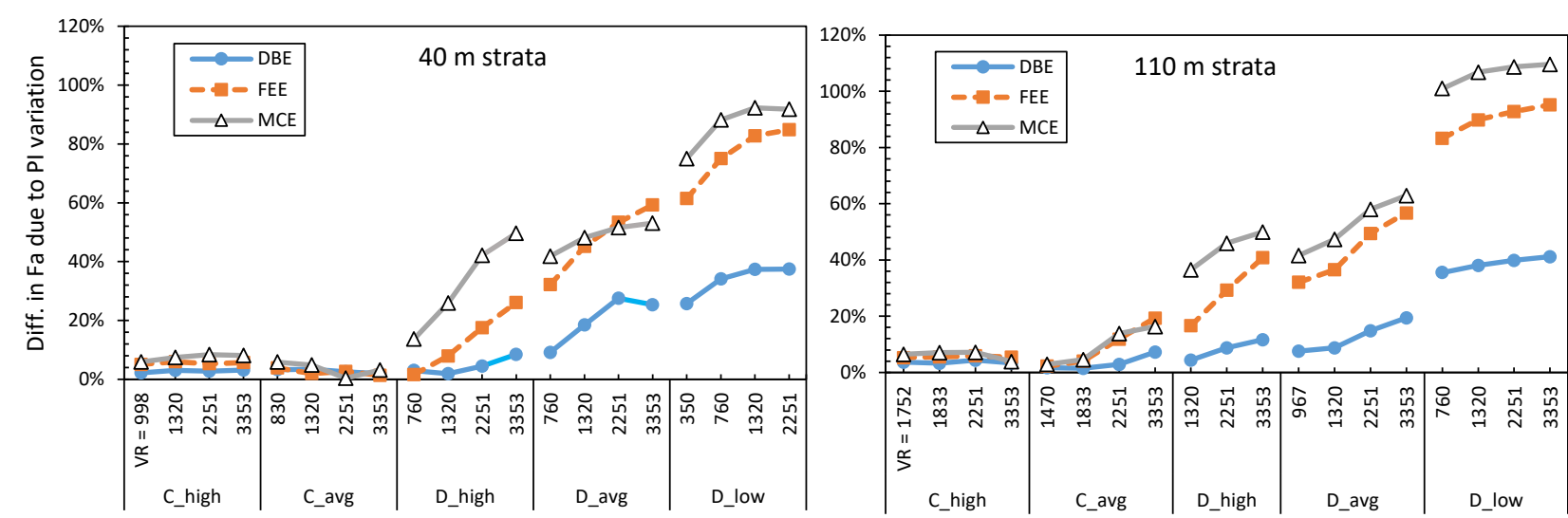

(a) Effect of PI on $F_{a}$
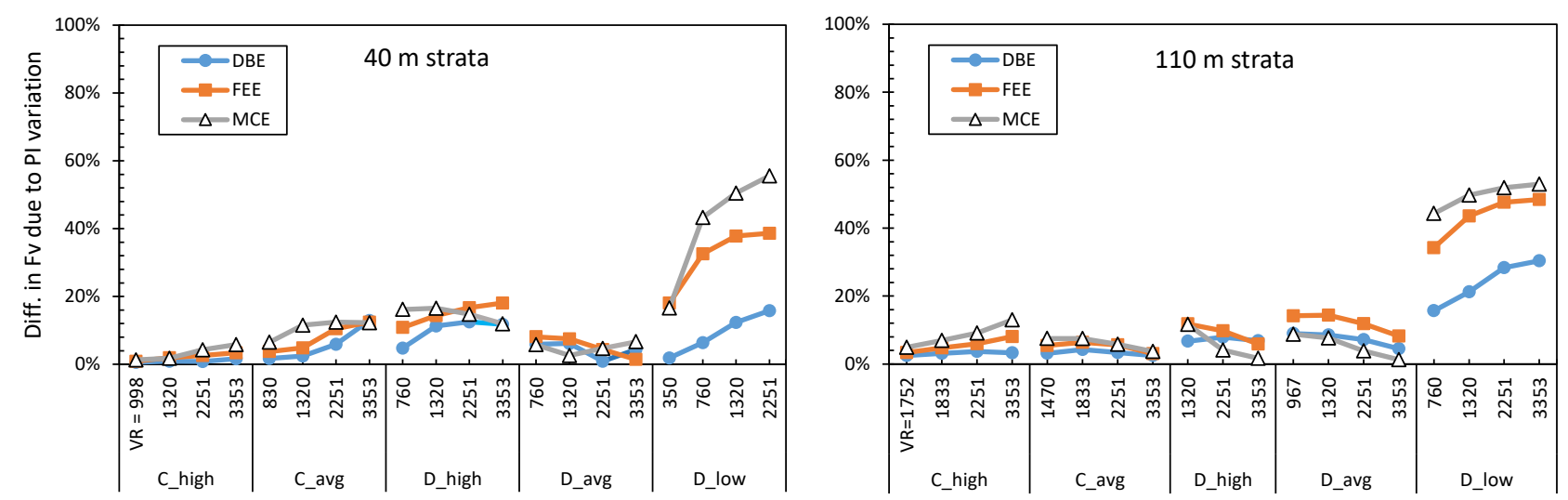

(b) Effect of PI on $F_{v}$

Figure 8: Effect of PI on $F_{a}$ and $F_{v}$ for various earthquake intensities, site classes and $V_{\text {rock. }}$ 


\section{Effect of Earthquake Intensity on $F_{a}$}

$F_{a}$ values for site class $C$ _high were very slightly affected by increasing level of earthquake intensity for all values of $V_{\text {rock }}$ and all three values of PI as depicted in Fig. 10. Similarly, for site class C_avg, there was no effect on $F_{a}$ values for lower values of $\mathrm{V}_{\text {rock}}$, while a slight decreasing trend was observed for

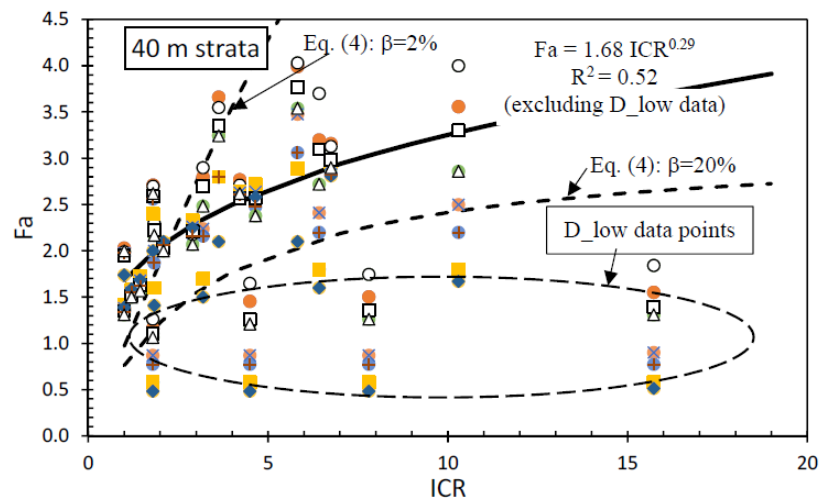

higher $\mathrm{V}_{\text {rock }}$ values. For site class $\mathrm{D}$ _high, the trend was similar to site class $C_{-}$avg but the trend for decrease in $\mathrm{F}_{\mathrm{a}}$ values with increasing earthquake intensity is moderate to high for higher values of $V_{\text {rock. }}$ On the other hand, sharp decrease in $F_{a}$ values are observed with increasing earthquake intensity for all $\mathrm{V}_{\text {rock }}$ values for site classes D_avg and D_low. This decrease in the amplification factor $F_{a}$ can be attributed to non-linearity in these

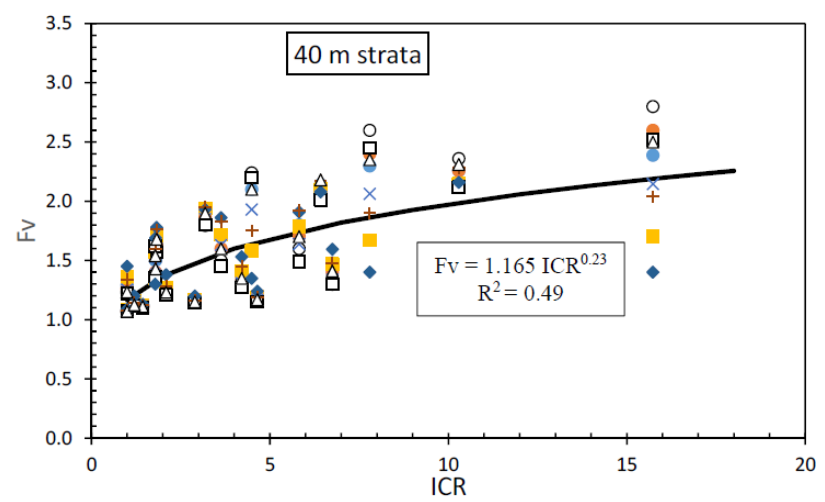

Figure 9: Relationship between Impedance Contrast Ratio (ICR) and soil amplification factors, $F_{a}$ \& $F_{v}$ for 40 m deep strata.
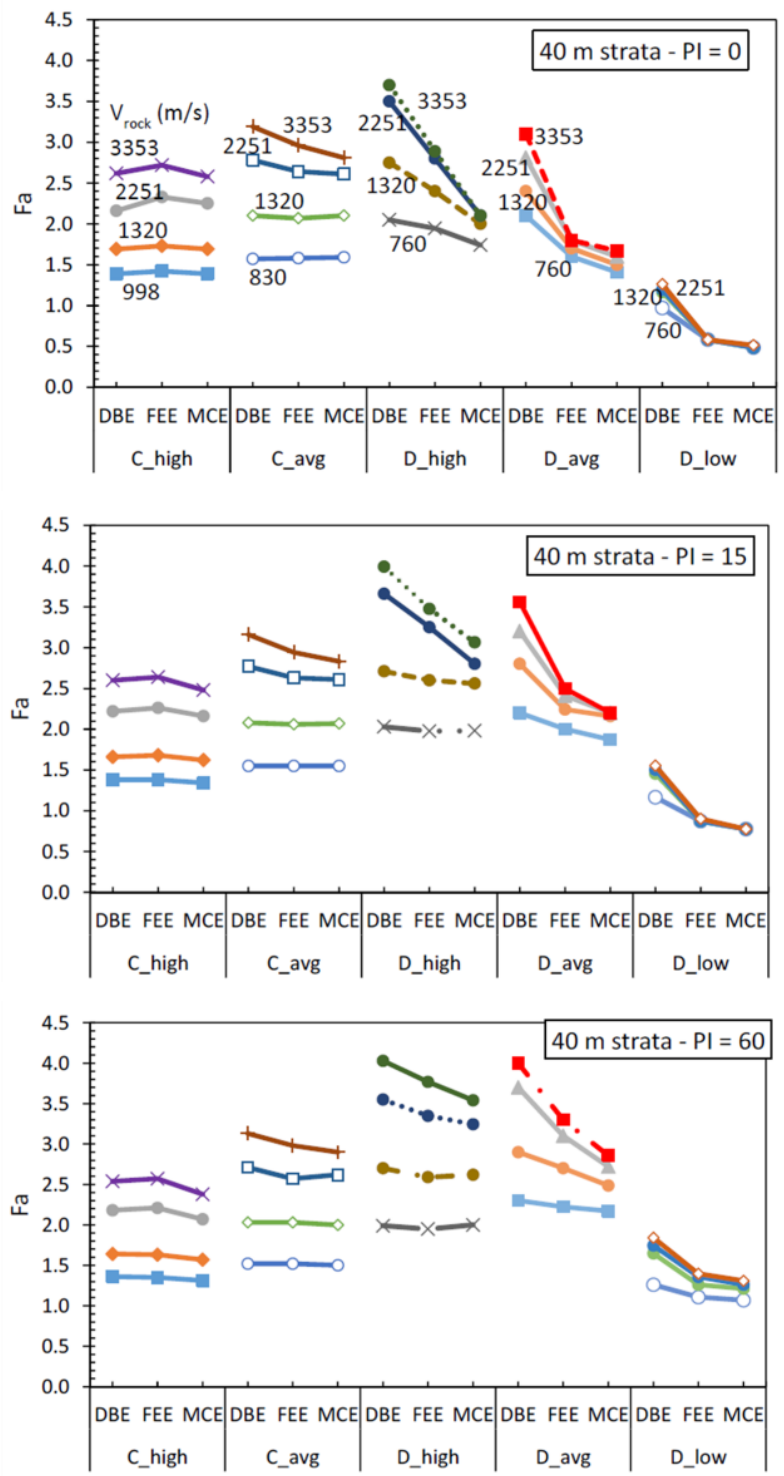

Figure 10: Variation of $F_{a}$ with earthquake intensity for various $V_{\text {rock }}$ and site classes for $40 \mathrm{~m}$ strata.
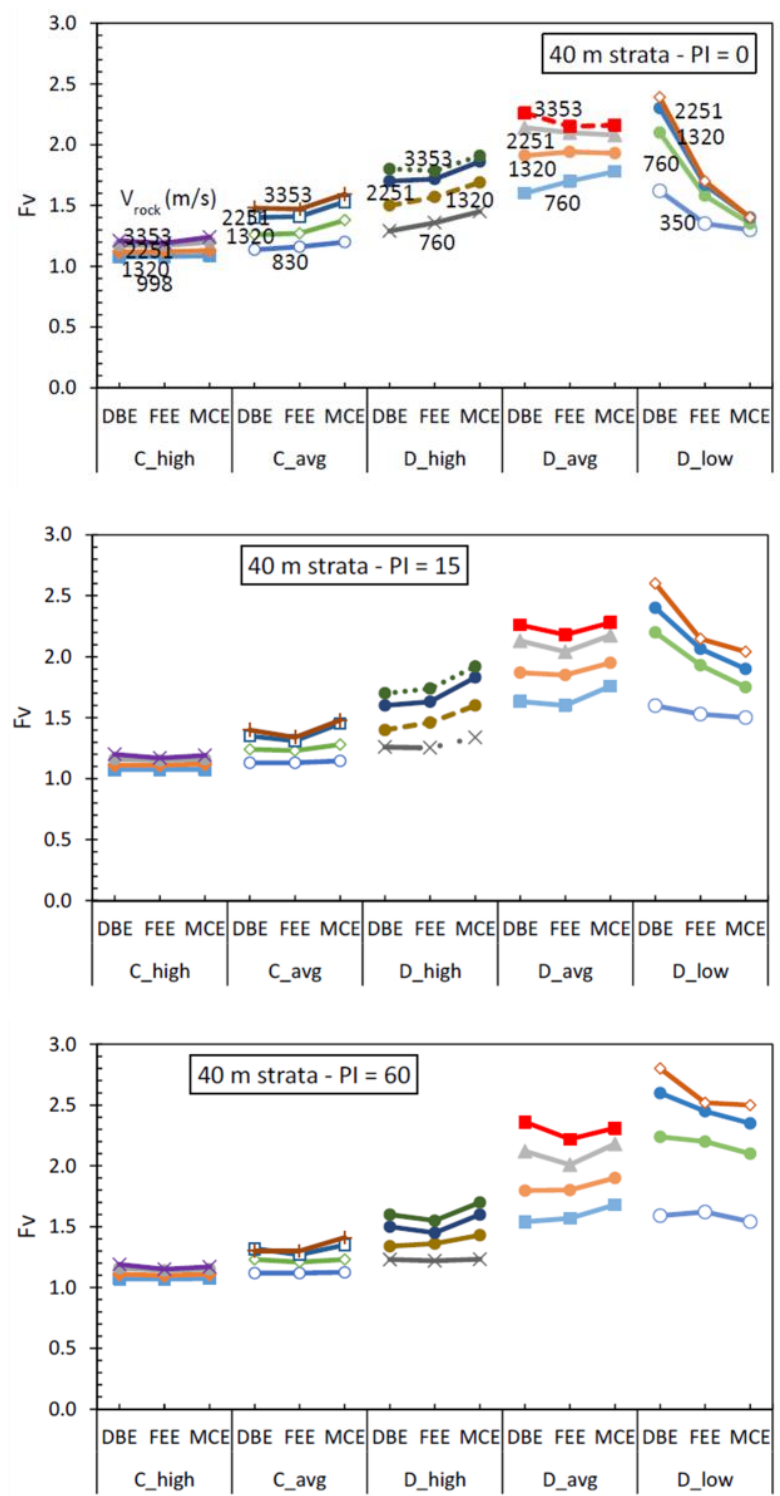

Figure 11: Variation of $F_{v}$ with earthquake intensity for various $V_{\text {rock }}$ and site classes for $40 \mathrm{~m}$ strata. 
weaker soils due to which high material damping was mobilized, which reduced the amplification factor.

\section{Effect of Earthquake Intensity on $F_{v}$}

Relationship between earthquake intensity and $\mathrm{F}_{\mathrm{v}}$ for various site classes and $V_{\text {rock }}$ values is presented in Fig. 11. Similar to $F_{a}$ values, $F_{v}$ values in site class $C_{-}$high were also unaffected by level of earthquake intensity. $\mathrm{F}_{\mathrm{v}}$ values for site class D_avg exhibited a mixed trend of slightly increasing for lower $V_{\text {rock }}$ values and slightly decreasing for higher $V_{\text {rock }}$ values. Contrary to the trend for $F_{a}$ values, $F_{v}$ values for site classes $C_{-}$avg and D_high showed an increasing trend with increasing earthquake intensity. This trend was more pronounced in site class D_high.
$\mathrm{F}_{\mathrm{v}}$ values for site class D_low showed a decreasing trend with increasing earthquake intensity which was similar to the $F_{a}$ values for this site class. However, this decreasing trend reduced with increasing PI values for this site class.

\section{Effect of Strata Depth}

The influence of strata depth on the values of amplification factors $\left(\mathrm{F}_{\mathrm{a}}\right.$ and $\left.\mathrm{F}_{\mathrm{v}}\right)$ was examined by plotting the ratio of the values for $110 \mathrm{~m}$ and $40 \mathrm{~m}$ strata as depicted in Fig. 12. The following observations were made.
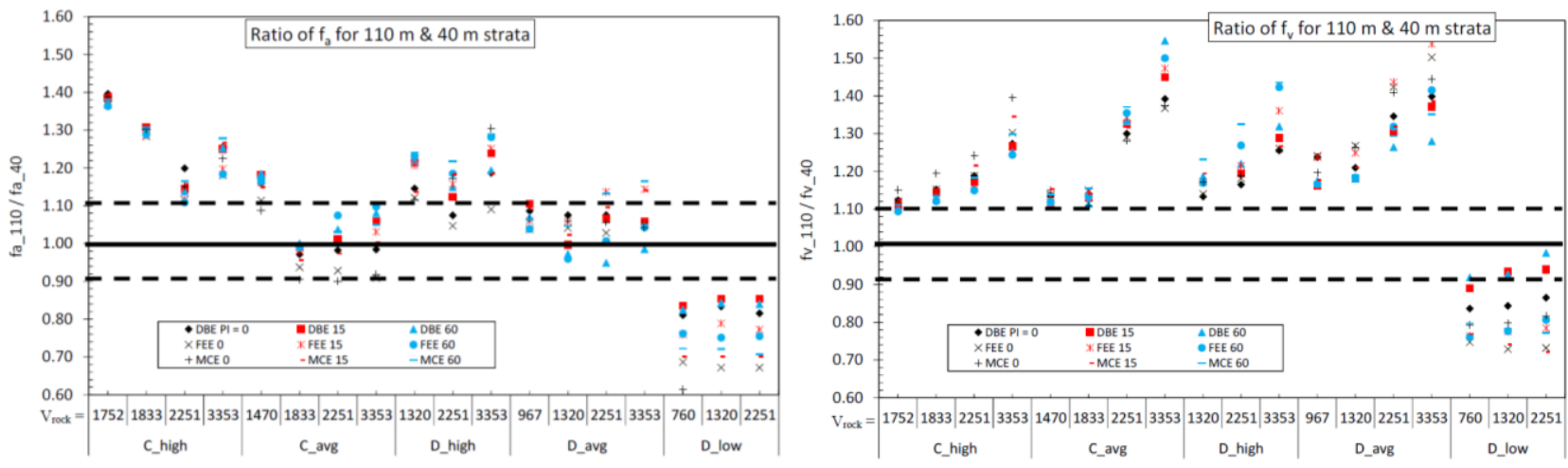

Figure 12: Influence of strata depth on short and medium period amplification factors $F_{a}$ and $F_{v}$ for various soil profiles.
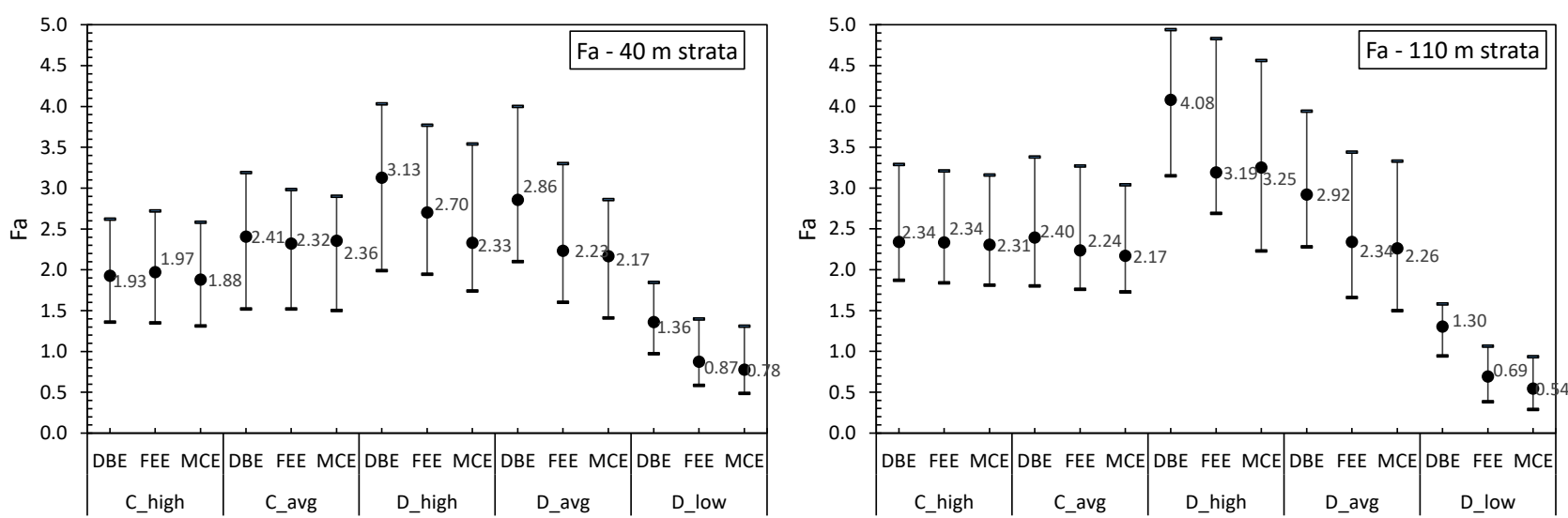

(a) Effect of site class on $F_{a}$
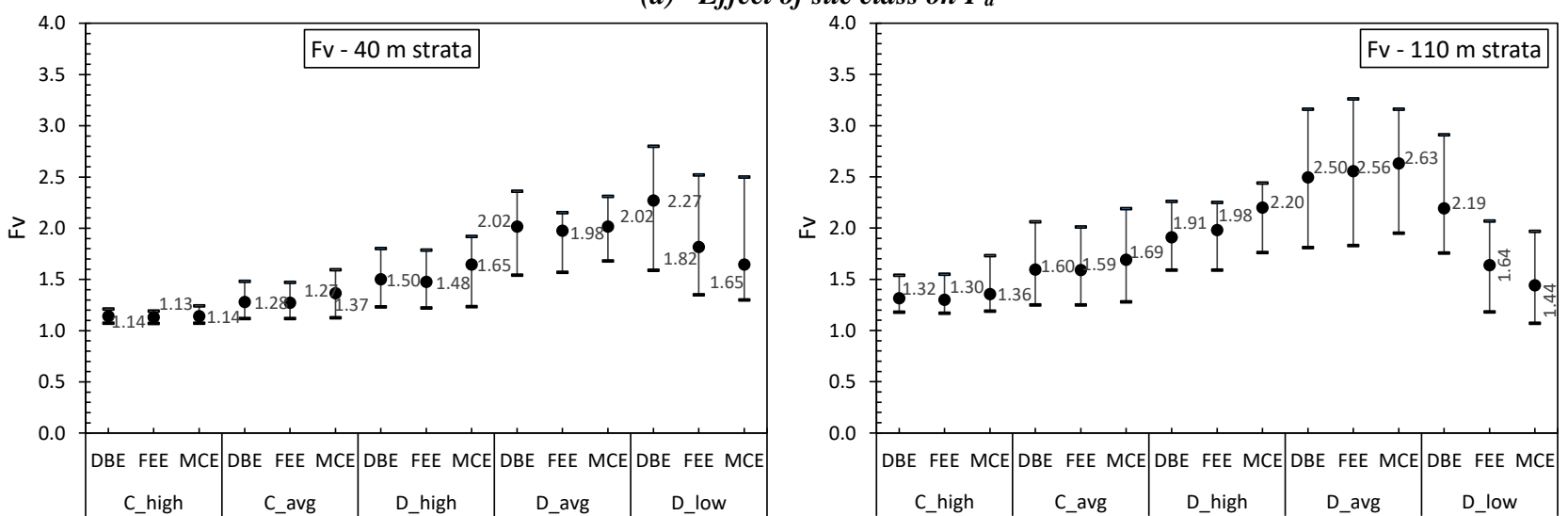

(b) Effect of site class on $F_{v}$

Figure 13: Effect of site class on $F_{a}$ and $F_{v}$ for various earthquake intensities. 


\section{Effect of Strata Depth on $F_{a}$}

Referring to Fig. 12, it was observed that the influence of strata depth on $F_{a}$ values for site classes C_avg and D_avg is minor as the ratio is within $\pm 10 \%$ of unity. There is a moderate influence of strata depth on $\mathrm{F}_{\mathrm{a}}$ values for site class $\mathrm{D}$ _high as the ratio is about $+20 \%$ above unity. However, there is a strong influence of strata depth on $\mathrm{F}_{\mathrm{a}}$ for site classes C_high and D_low as the ratio is more than $20 \%$ above and below unity for these site classes respectively. It is to be noted that site class D_low is the only site class in which the ratio is below unity (i.e. values are more for $40 \mathrm{~m}$ strata) for all data points. This anomaly could be attributed to the higher ICR values for the $40 \mathrm{~m}$ deep strata as compared to the $110 \mathrm{~m}$ strata.

\section{Effect of Strata Depth on Fv}

Examination of Fig. 12 for $F_{v}$ revealed that $F_{v}$ values for all site classes were moderately to strongly influenced by the strata depth. Moderate influence $(\approx+20 \%)$ was noted for site class C_high and some cases of C_avg. However, strong positive influence $(>+20 \%)$ was noted for site classes D_high and D_avg and a strong negative influence $(>-20 \%)$ was observed for site class D_low. It was noted that site class D_low was the only site class in which the ratio was below unity (i.e. values were more for $40 \mathrm{~m}$ strata) for all data points. This anomaly could be attributed to the higher ICR value for the $40 \mathrm{~m}$ deep strata as compared to the $110 \mathrm{~m}$ strata.

\section{Effect of Site Class}

Effect of site class on amplification factors $F_{a}$ and $F_{v}$ for both strata depths was examined in Fig. 13 by plotting the maximum, median and minimum values of the amplification factors for a given earthquake intensity. The maximum, median and minimum values were determined for all $\mathrm{PI}$ and $\mathrm{V}_{\text {rock }}$ values for a particular site class (e.g. C_high) and earthquake intensity (e.g. DBE).

It was observed that $F_{a}$ values for both $40 \mathrm{~m}$ and $110 \mathrm{~m}$ strata slightly increased from site class C_high to C_avg, then attained peak values for site class D_high and then showed a steady decrease for site classes D_avg and D_low. The trend for $F_{v}$ values was different from $F_{a}$ as $F_{v}$ values continued to increase from site classes C_high to C_avg to D_high and attained the peak values for site class $D_{-}$avg. Afterwards, $F_{v}$ values decreased for site class D_low.

\section{Effect of Soil Non-linearity on Site Amplification Factors}

An equivalent linear 1-D site response analysis was carried out in the presented study. It is understood [48 - 50] that use of nonlinear site response analysis may be required under certain situations of site class and seismicity level. It is demonstrated in [50] that the equivalent linear response is essentially the same as the non-linear response for peak soil shear strains $(\gamma)$ of less than $0.1 \%$ and equivalent linear response analysis can be used with high confidence for such cases. For strains between $0.1 \%$ and $1 \%$, the equivalent linear response starts to diverge from the non-linear response and equivalent linear response analysis should be used with caution. Whereas, for soil shear strains greater than $1 \%$, use of non-linear response analysis is essential [50].

It was noted in the study presented herein that the median peak soil shear strain $(\gamma)$ value for site classes C_high and C_avg was less than the lower threshold value of $0.1 \%$ for all PI values, ground motions and for both strata depths. Therefore, using equivalent linear response analysis is not expected to cause any discrepancy in the results for these site classes. For site class D_high and D_avg, $\gamma$ exceeded the lower threshold of $0.1 \%$ for most of the MCE ground motions in a limited depth $(<6 \mathrm{~m}$ at the top) with a maximum median values of $0.16 \%$ and $0.3 \%$ for site classes D_high and D_avg respectively. However, for site class D_low, $\gamma$ exceeded the lower threshold of $0.1 \%$ for all ground motions and registered a maximum value of $0.8 \%$ for earthquake ID \# 32. This means that a non-linear response analysis may have resulted in different values of amplification factors for only a limited number of site classes under certain earthquake intensities. Therefore, the conclusions reached in this study are still valid despite the use of an equivalent-linear seismic site response analysis.

\section{Summary of the Sensitivity Analysis}

Tables 6 and 7 summarize results of the sensitivity analysis for $F_{a}$ and $F_{v}$ respectively for various parameters based on the discussion presented earlier in the section. The influence of a parameter on soil amplification factors is quantified as follows: Ignore $(<10 \%)$, Low $(10 \sim 20 \%)$, Moderate $(20 \sim 50 \%)$, High (50 80\%), Very high $(>80 \%)$. The following observations were made:

i- Referring to Fig. 8, it was noted that $F_{a}$ and $F_{v}$ values for soil profiles in site class $C$ were unaffected due to variation in the PI values, whereas these values for soil profiles in site class D were highly dependent on the PI values. The influence of PI on $F_{a}$ and $F_{v}$ values increased with decreasing $\mathrm{V}_{\mathrm{s} 30}$ of the site classes.

ii- It was observed in Figs. 6 and 7 that variation in $\mathrm{V}_{\text {rock }}$ had a high influence on $F_{a}$ values for soil profiles in site class $C$ and for $F_{v}$ values in site class $D$, while it had low to moderate influence on $F_{a}$ values in site class $D$ and $F_{v}$ values in site class $C$. The influence of $V_{\text {rock }}$ on $F_{a}$ values was opposite to that of the PI and its impact decreased with decreasing $V_{s 30}$ of the site class. Whereas, for $F_{v}$ values, $\mathrm{V}_{\text {rock }}$ influence increased with decreasing $\mathrm{V}_{\mathrm{s} 30}$ of the site class.

iii- As depicted in Figs. 10 and 11, variation in earthquake intensity had high influence on $F_{a}$ values in site class D only

Table 6: Summary of sensitivity analysis for $F_{a}$.

\begin{tabular}{|c|c|c|c|c|}
\hline \multirow{2}{*}{$\begin{array}{c}\text { Site } \\
\text { Class }\end{array}$} & PI & $\mathrm{V}_{\text {rock }}$ & $\begin{array}{c}\text { Earthquake } \\
\text { intensity }\end{array}$ & $\begin{array}{c}\text { Strata } \\
\text { depth }\end{array}$ \\
\cline { 2 - 5 } C_high & Ignore & High & Ignore & Moderate \\
\hline C_avg & Ignore & High & Ignore & $\begin{array}{c}\text { Ignore } \\
( \pm)\end{array}$ \\
\hline D_high & Moderate & High & Low (-) & Moderate \\
\hline D_avg & High & Moderate & High (-) & $\begin{array}{c}\text { Ignore } \\
( \pm)\end{array}$ \\
\hline D_low & Very & Ignore & High (-) & $\begin{array}{c}\text { Moderate } \\
(-)\end{array}$ \\
\hline
\end{tabular}

Table 7: Summary of sensitivity analysis for $F_{v}$.

\begin{tabular}{|c|c|c|c|c|}
\hline \multirow[b]{2}{*}{$\begin{array}{c}\text { Site } \\
\text { Class }\end{array}$} & \multicolumn{4}{|c|}{ Parameter } \\
\hline & PI & $V_{\text {rock }}$ & $\begin{array}{c}\text { Earthquake } \\
\text { intensity }\end{array}$ & $\begin{array}{l}\text { Strata } \\
\text { depth }\end{array}$ \\
\hline C_high & Ignore & Low & Ignore & Moderate \\
\hline C_avg & Ignore & Moderate & Low & Moderate \\
\hline D_high & Moderate & & Low & Moderate \\
\hline D_avg & Low & High & Low $( \pm)$ & Moderate \\
\hline D_low & High & Moderate & $\begin{array}{c}\text { Moderate } \\
(-)\end{array}$ & $\begin{array}{c}\text { Moderate } \\
(-)\end{array}$ \\
\hline
\end{tabular}

Key:

Ignore (< 10\%), Low (10 20\%), Moderate (20 50\%), High (50 $80 \%)$, Very high $(>80 \%$

Value of $F_{a}$ or $F_{v}$ increases with increasing value of the sensitivity parameter unless noted by the indicator in parenthesis. 


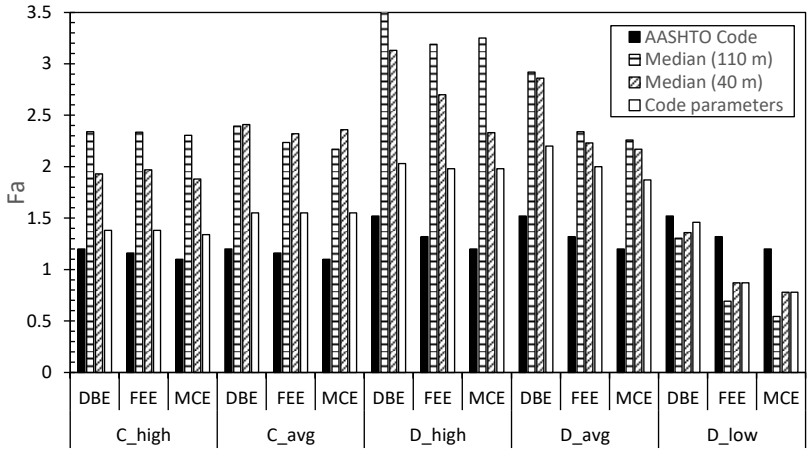

(a) $F_{a}$

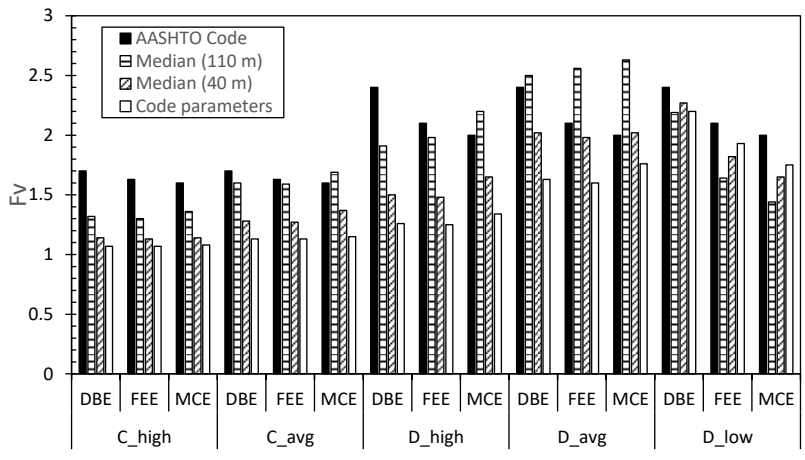

(b) $F_{v}$

Figure 14: Comparison of computed values of soil amplification factors with AASHTO Code.

and its influence was low to moderate for $\mathrm{F}_{\mathrm{v}}$ values in all site classes. The trend of the earthquake intensity influence was similar to that of PI and its impact increased with decreasing $\mathrm{V}_{\mathrm{s} 30}$ of site class for both $\mathrm{F}_{\mathrm{a}}$ and $\mathrm{F}_{\mathrm{v}}$ (refer to Figs. 6 and 7). This higher influence of earthquake intensity on $F_{a}$ and $F_{v}$ values in site class $D$ could be due to higher level of shear strains induced in this site class as noted in Section 4.6.

iv- Strata depths considered in the study had a low to moderate influence on $F_{a}$ and $F_{v}$ values for all site classes. The effect of strata depth could be even ignored for $F_{a}$ values in site classes C_avg and D_avg. No discernible trend in the influence of strata depth on $F_{a}$ and $F_{v}$ values was noticed with respect to $\mathrm{V}_{\mathrm{s} 30}$ of the strata.

\section{COMPARISON OF COMPUTED VALUES OF AMPLIFICATION FACTORS WITH AASHTO CODE}

Median values of soil amplification factors $\left(F_{a}\right.$ and $\left.F_{v}\right)$ as computed earlier were compared with the values stipulated in the AASHTO code in Fig. 14. In these figures, median values for $40 \mathrm{~m}$ and $110 \mathrm{~m}$ strata were compared with the code values. Additionally, soil amplification factor values for parameters similar to the ones that were used to derive the code values, i.e. strata depth of $40 \mathrm{~m}, \mathrm{PI}=15$ and $\mathrm{V}_{\text {rock }}=760 \sim 900 \mathrm{~m} / \mathrm{s}$ [3], were also plotted in this figure. The following observations were made:

\section{Fa Values [Refer to Fig. 14(a)]}

i- Median values of amplification factor $F_{a}$ computed in this study were $50 \%$ to $160 \%$ more than the code values for site classes C_high, C_avg, D_high and D_avg.

ii- Median values of $\mathrm{F}_{\mathrm{a}}$ computed in this study for site class D_low were $30 \%$ to $60 \%$ smaller than the code values.

iii- $F_{a}$ values computed for parameters similar to code conditions were within $+11 \%$ to $+65 \%$ of the code values for site classes C_high, C_avg, D_high and D_avg. and $18 \%$ to $-40 \%$ for site class $D_{-}$low. This implies that the procedure adopted in the study is reliable and the values reported for other cases and the conclusions drawn from the sensitivity analysis are valid.

iv- Smaller values of $F_{a}$ for the weakest site class (D_low) as compared to the code value are also no surprise as others had also reported similar findings [11, 13]. Physical explanation for this fact may be the increased soil shear strains and soil non-linearity as noted earlier.

\section{$F_{v}$ Values [Refer to Fig. 14(b)]}

i- $F_{v}$ values exhibited less variation w.r.t. code values as compared to the $\mathrm{F}_{\mathrm{a}}$ values. Most of the computed values were smaller than the code values by $1 \%$ to $42 \%$ for all site classes except site class D_avg for which the computed values were $3 \%$ to $34 \%$ higher than the code values.

ii- $F_{v}$ values computed for parameters similar to code conditions were within $-7 \%$ to $-50 \%$ of the code values for all site classes.

\section{CONCLUSIONS}

The following conclusions are drawn from this study, which are applicable only to the site and geotechnical parameters considered in the study. Extrapolation to other site and geotechnical conditions should be done with caution while exercising engineering judgement.

i- It is concluded from the results of more than 3950 1-D site response analysis, computation of soil amplification factors and results of sensitivity analysis that the soil amplification factors for AASHTO site classes C and D showed varying degree of dependence on geological setting and geotechnical properties as well as strata depth and earthquake intensity.

ii- Bedrock properties and soil PI were found to be the two most influential parameters affecting soil amplification factors, $F_{a}$ and $F_{v}$. Bedrock properties affected the $F_{a}$ and $F_{v}$ values for sites with higher $V_{s 30}$ while variation in PI influenced these parameters for sites with smaller $\mathrm{V}_{\mathrm{s} 30 \text {. }}$

iii- Earthquake intensity did not have an appreciable influence on $F_{a}$ and $F_{v}$ values for sites with higher $V_{s 30}$ but for other sites, $F_{a}$ values decreased with increasing earthquake intensity. However, earthquake intensity did not affect $F_{v}$ values for sites with lower $\mathrm{V}_{\mathrm{s} 30}$.

iv- Strata depth had a low to moderate influence on $F_{a}$ and $F_{v}$ values in all site classes except for site classes C_avg and D_avg for which its effect on $F_{a}$ values could be ignored. However, this conclusion was based on the study conducted on two strata depths (i.e. $40 \mathrm{~m}$ and $110 \mathrm{~m}$ ) only. Additional strata depths should be analysed to fully appreciate the influence of strata depth on $F_{a}$ and $F_{v}$.

v- Soil amplification factors computed for conditions similar to the one used for finding these factors in AASHTO code varied between $11-60 \%$ for $\mathrm{F}_{\mathrm{a}}$ and $-7--48 \%$ for $\mathrm{F}_{\mathrm{v}}$ with an average variation of $35 \%$ and $-27 \%$ for $F_{a}$ and $F_{v}$ respectively. It is to be noted that the computed $F_{v}$ values were generally lower than the code values. 
vi- There is a need to include a disclaimer in the AASHTO code for use of the specified $F_{a}$ and $F_{v}$ values for site conditions not included in the derivation of these factors. Users should be asked to seek alternative soil amplification factors for sites with harder bedrock $\left(\mathrm{V}_{\text {rock }}>900 \mathrm{~m} / \mathrm{s}\right)$, strata depth other than $30-40 \mathrm{~m}$ and PI different than 15-30.

\section{ACKNOWLEDGEMENTS}

This work was supported by Kuwait University, Research Grant No. EV01/15

\section{REFERENCES}

1 Elnashai AS and DiSarno L (2008). "Fundamentals of Earthquake Engineering”. Wiley \& Sons, UK.

2 AASHTO (2014). "AASHTO LRFD Bridge Design Specifications, $7^{\text {th }}$ Edition". American Association of State Highway and Transportation Officials, Washington, DC.

3 Dobry R, Borcherdt RD, Crouse CB, Idriss IM, Joyner WB, Martin GR and Seed RB (2000). "New Site Coefficients and Site Classification System Used in Recent Building Seismic Code Provisions". Earthquake Spectra, 16(1): 41-67.

4 Borcherdt RD (1997). "Estimates of Site-Dependent Response Spectra for New and Existing Highway Facilities (Methodology and Justification)". Proceedings of FHWA/NCEER Workshop on the National Representation of Seismic Ground Motion for New and Existing Highway Facilities, Edited by: IM Friedland, MS Power and RL Mayes, Technical Report NCEER-97-0010, pp. 171-201, Buffalo, NY.

5 Nikolaou S, Mylonakis $\mathrm{G}$ and Edinger $\mathrm{P}$ (2001). "Evaluation of Site Factors for Seismic Bridge Design in New York City Area”. Journal of Bridge Engineering, 6(6): 564-576.

6 Kim DS, Chung CK, Sun CG and Bang ES (2002). "Site Assessment and Evaluation of Spatial Earthquake Ground Motion of Kyeongju”. Soil Dynamics and Earthquake Engineering, 22(5): 371-387.

7 Kalkan E and Gülkan P (2004). "Site-dependent Spectra Derived from Ground Motion Records in Turkey”. Earthquake Spectra, 20(4): 1111-1138.

8 Rathje EM, Kottke AR and Trent WL (2010). "Influence of Input Motion and Site Property Variabilities on Seismic Site Response Analysis". Journal of Geotechnical and Geoenvironmental Engineering, 136(4): 607-619.

9 Jayaram N, Baker JW, Okano H, Ishida H, McCann Jr. MW and Mihara Y (2011). "Correlation of Response Spectral Values in Japanese Ground Motions". Earthquake and Structures, 2(4): 357-376.

10 Andreotti G, Lai GC, Bozzoni F and Scandella L (2013). "New Soil Factors for the Italian Building Code (NTC08) Derived from 1D Fully Stochastic Ground Response Analyses". XV Convegno ANIDIS, Padova, Italy, Vol. 30.

11 Dhakal RP, Lin SL, Loye AK and Evans SJ (2013). "Seismic Design Spectra for Different Soil Classes". Bulletin of the New Zealand Society for Earthquake Engineering, 46(2): 79-87.

12 Gautam D, Forte G and Rodrigues H (2016). "Site Effects and Associated Structural Damage Analysis in Kathmandu Valley, Nepal". Earthquake and Structures, 10: 1013-1032.

13 Manandhar S, Cho HI and Kim DS (2016). "Effect of Bedrock Stiffness and Thickness of Weathered Rock on Response Spectrum in Korea". KSCE Journal of Civil Engineering, 20(7): 2677-2691.

14 Pitilakis K, Gazepis C and Anastasiadis A (2004). "Design Response Spectra and Soil Classification for Seismic Code Provisions". Proceedings of the $13^{\text {th }}$ World Conference on
Earthquake Engineering, Paper No. 2904, Vancouver, Canada.

15 Papaspiliou M, Kontoe S and Bommer JJ (2012). “An Exploration of Incorporating Site Response into PSHAPart I: Issues Related to Site Response Analysis Methods". Soil Dynamics and Earthquake Engineering, 42: 302-315.

16 European Committee for Standardization (2003). "Eurocode 8: Design Provisions for Earthquake Resistance of Structures, Part 1.1: General Rules, Seismic Actions and Rules for Buildings". Brussels, 232 pp.

17 Japan Road Association (2012). "Design Specifications for Highway Bridges, Part V: Seismic Design". Japan Road Association, Tokyo, Japan.

18 Standards New Zealand (2002). "AS/NZS 1170.0: Structural Design Actions, Part 0: General Principles". Standards Australia/Standards New Zealand, Wellington, New Zealand.

19 Fukushima Y, Bonilla LF, Scotti O and Douglas J (2007). "Site Classification Using Horizontal-to-Vertical Response Spectral Ratios and its Impact When Deriving Empirical Ground-Motion Prediction Equations". Journal of Earthquake Engineering, 11(5): 712-724.

20 Kouretzis GP, Masia MJ and Allen C (2013). "Structural Design Codes of Australia and New Zealand: Seismic Actions". In: Beer M, Kougioumtzoglou I, Patelli E, Au IK (editors), Encyclopedia of Earthquake Engineering, Springer, Berlin, Germany.

21 Douglas J, Gehl P, Bonilla LF, Scotti O, Régnier J, Duval AM and Bertrand E (2009). "Making the Most of Available Site Information for Empirical Ground-Motion Prediction". Bulletin of the Seismological Society of America, 99(3): 1502-1520.

22 Toro GR (1995). "Probabilistic Models of Site Velocity Profiles for Generic and Site-Specific Ground-Motion Amplification Studies". Brookhaven National Laboratory, Upton, New York.

23 Chaudhary MTA (2017). "Seismic Response of Bridges Supported on Shallow Rock Foundations Considering SSI and Pier Column Inelasticity". KSCE Journal of Civil Engineering, 21(1): 285-295.

24 Bieniawski ZT (1974). "Geomechanics Classification of Rock Masses and its Application in Tunneling". Proceedings of the 3rd International Congress on Rock Mechanics, ISRM, Denver, 2(2): 27-32.

25 Kottke AR and Rathje EM (2008). "Technical Manual for Strata". PEER Report 2008/10. University of California, Berkeley, California, http://nees.org/resources/strata.

26 Burmister DM (1949). "Principles and Techniques of Soil Identification". Proceedings of $29^{\text {th }}$ Annual Highway Research Board meeting, National Research Council, Washington, DC. pp. 402-433.

27 Guerreiro P, Kontoe S and Taborda D (2012). "Comparative Study of Stiffness Reduction and Damping Curves". $15^{\text {th }}$ World Conference on Earthquake Engineering, Lisbon, CD ROM, pp. 1-10.

28 Darendeli MB (2001). "Development of a New Family of Normalized Modulus Reduction and Material Damping Curves". PhD thesis, University of Texas, Austin, 394 pp.

29 Vucetic M and Dobry R (1991). "Effect of Soil Plasticity on Cyclic Response". Journal of Geotechnical Engineering, 117(1): 87-107.

30 Ishibashi I and Zhang X (1993). "Unified Dynamic Shear Moduli and Damping Ratios of Sand and Clay". Soils and Foundations, 33(1), 182-191. 
31 Federal Emergency Management Agency (2008). "ATC-63. Quantification of Building Seismic Performance Factors". ATC-63, Project Report prepared by the Applied Technology Council for the Federal Emergency Management Agency, Washington, DC.

32 Federal Emergency Management Agency (2009). "FEMA P-750. NEHRP Recommended Seismic Provisions for New Buildings and Other Structures". Building Seismic Safety Council, Washington, DC, USA.

33 Haselton CB, Baker JW, Stewart JP, Whittaker AS, Luco N, Fry A and Pekelnicky RG (2017). "Response History Analysis for the Design of New Buildings in the NEHRP Provisions and ASCE/SEI 7 Standard: Part I-Overview and Specification of Ground Motions". Earthquake Spectra, 33(2): 373-395.

34 Katsanos EI and Sextos AG (2013). "ISSARS: An Integrated Software Environment for Structure-Specific Earthquake Ground Motion Selection". Advances in Engineering Software, 58: 70-85.

35 Stewart JP, Afshari K and Hashash YM (2014). "Guidelines for Performing Hazard-Consistent One-Dimensional Ground Response Analysis for Ground Motion Prediction". PEER Report, 2014/16, Berkeley, CA.

36 Chaudhary MTA (2016). "Implication of Soil and Seismic Ground Motion Variability on Dynamic Pile Group Impedance for Bridges". Project Report No. EV01/15, Research Sector, Kuwait University, Kuwait.

37 Pacific Center for Earthquake Engineering Research (2017). "PEER NGA-West2 Ground Motion Database". Pacific Center for Earthquake Engineering Research, Berkeley, CA. http://ngawest2.berkeley.edu/

38 Dhakal RP, Lin SL, Loye AK and Evans SJ (2013). "Closure to Seismic Design Spectra for Different Soil Classes". Bulletin of the New Zealand Society for Earthquake Engineering, 46(4): 222-225.

39 Seed HB, Ugas C and Lysmer J (1976). "Site-Dependent Spectra for Earthquake-Resistant Design". Bulletin of the Seismological society of America, 66(1): 221-243.

40 Borcherdt RD (1994). "Estimates of Site-Dependent Response Spectra for Design (Methodology and Justification)". Earthquake Spectra, 10(4): 617-653.

41 Rey J, Faccioli E and Bommer JJ (2002). "Derivation of Design Soil Coefficient(s) and Response Spectral Shapes for Eurocode 8 Using the European Strong-Motion Database". Journal of Seismology, 6(4): 547-555.
42 Pitilakis K, Riga E and Anastasiadis A (2013). "New Code Site Classification, Amplification Factors and Normalized Response Spectra Based on a Worldwide Ground-Motion Database". Bulletin of Earthquake Engineering, 11(4): 925966.

43 Borcherdt RD (1996). "Preliminary Amplification Estimates Inferred from Strong Ground Motion Recordings of the Northridge Earthquake Of January 17, 1994". Proceedings of the International Workshop on Site Response Subjected to Strong Ground Motion, edited by Iai, Yokosuka, Japan, Vol. 2, pp. 21-46.

44 Dobry R, Ramos R and Power MS (1999). "Site Factor and Site Categories in Seismic Codes". Technical Report MCEER-99-0010, Multidisciplinary Center for Earthquake Engineering Research, Buffalo, NY.

45 Building Seismic Safety Council (1997). "FEMA 302/303, NEHRP Recommended Provisions for Seismic Regulations for New Buildings and Other Structures, Part 1 (Provisions) and Part 2 (Commentary)". Building Seismic Safety Council, Washington, DC.

46 Roesset JM (1977). "Soil Amplification in Earthquakes". Numerical Methods in Geotechnical Engineering, Edited by C.S. Desai and J.T. Christian, Chapter 19, McGraw Hill, NY, 639-682.

47 Devore J and Farnum N (2013). "Applied Statistics for Engineers and Scientists". $2^{\text {nd }}$ Edition, Cengage Learning, Toronto.

48 Kim B, Hashash YMA, Stewart JP, Rathje EM, Harmon JA, Musgrove MI, Campell KW and Silva WJ (2016). "Relative Differences between Nonlinear and Equivalent-Linear 1D Site Response Analyses". Earthquake Spectra, 32(3): 18451865.

49 Kaklamanos J, Baise LG, Thompson EM and Dorfmann L (2015). "Comparison of 1D Linear, Equivalent-Linear, and Nonlinear Site Response Models at Six Kik-Net Validation Sites". Soil Dynamics and Earthquake Engineering, 69: 207-219.

50 Bolisetti, C, Whittaker AS, Mason HB, Almufti I and Willford M (2014). "Equivalent Linear and Nonlinear Site Response Analysis for Design and Risk Assessment of Safety-Related Nuclear Structures". Nuclear Engineering and Design, 275: 107-121. 